\title{
I Direct Pursuit of Knowledge of the Transcendent Truth
}

\section{I.1 Definitions and Contextualizations}

In this chapter, I explore the textual articulations pertaining to a direct pursuit of knowledge of the transcendent truth in both our texts. The first step will be to inquire into the presence of knowledge and its pursuit in both texts. Then I define the form of knowledge in question. Furthermore, I define the boundaries of knowledge and the quest for knowledge within which Goethe's nineteenthcentury drama can be compared to the fourteenth-century Divan of Šams ud-Dīn Muḥammad Ḥāfiz of Shiraz (Šīāz). In this chapter, based on definitions discussed below, I explore the significance of the pursuit of knowledge in regard to the way the seeker of knowledge values and treats the body and soul. In the chapters that follow, I explore possible modifications of the approach, object of pursuit, and significance of the body and soul in Goethe's Faust and Ḥāfiẓ’s Divan.

\section{I.1.1 The Representation of Knowledge in the Beginning of Faust I}

The reader starts to construct an image of Faust's character from the following verses in the Prolog im Himmel:

\author{
DER HERR \\ Kennst du den Faust? \\ MEPHISTOPHELES \\ Den Doktor? \\ DER HERR \\ Meinen Knecht! ${ }^{1}$
}

The Lord is the first one to mention Faust's name; Mephistopheles immediately recognizes him as 'the doctor'. 'The co-presence of the Lord and Mephistopheles in this scene highlights two aspects of Faust: as an individual, he is 'der Doktor'; but Faust is also 'der Knecht', a description that alludes to the Biblical story of Job: 'Der Herr sprach zu dem Satan: Hast du nicht acht auf meinen Knecht Hiob

1 V. 299.

2 This manner of introducing Faust is an allusion to the biblical story of Job. (Job 1: 6-12) See: FK, pp. 170-171.

๑ Open Access. ( 2019 Hiwa Michaeli, published by De Gruyter. (c) BY-NC-ND This work is licensed under a Creative Commons Attribution-NonCommercial-NoDerivatives 4.0 International License.

https://doi.org/10.1515/9783110661576-002 
gehabt? ${ }^{3}$ While most of the drama depicts Faust as an individual free from a predetermined destiny ('der Doktor'), ${ }^{4}$ in the scene Bergschluchten, the other aspect of Faust ('der Knecht') comes to the fore. It is, however, undeniable that the mention of Faust's name in the Prolog im Himmel - a scene in which all the archangels as well as Mephistopheles are gathered in a heavenly assembly opens the way for the reader to form interpretations that are of a transhistorical and archetypical nature. ${ }^{5}$ Yet this does not justify a reading that approaches the text as an account of a predetermined fate written in heaven. Rather, the drama goes through its chain of events in accordance with the logic that the work itself constructs as it unfolds.

Mephistopheles describes Faust as an individual full of longing and restlessness: 'Und alle Näh' und alle Ferne | Befriedigt nicht die tiefbewegte Brust. ${ }^{6}$ Yet the cause of his discontent is unknown. The curious reader who carries this question with him to the scene Nacht finds Faust no less restless and lost than he was (as Mephistopheles describes him) in the Prolog im Himmel, but at least in the scene Nacht the reasons for Faust's agonies are explained. In his opening soliloquy, Faust makes it known that he is a polymath, ever longing for more knowledge. Four branches of knowledge are mentioned. The first is philosophy and the last, named with explicit irony, is theology - or as Faust says, 'leider auch Theologie!' It is clear why the drama is considered a 'Gelehrtentragödie'. ${ }^{7}$ While introducing Faust I as oriented around two main themes, ${ }^{8}$ Trunz rightly points out that what Faust expects to achieve is 'durch

3 Hiob 2,3. In: 'Die Bible oder die gantze Heilige Schrift des Alten und Neuen Testaments / nach der Übers. Martin Luthers. Neu durchges. nach dem Dt. Evang. Kirchenausschuss genehm. Text,' (Stuttgart: Privil. Württemb. Bibelanstalt, 1954), p. 520.

4 Compare to FK, p. 164.

5 Günter Niggl, 'Biblische Welt in Goethes Dichtung', in 'Im Anschauen ewger Liebe': Von Goethe lernen, ed. Wolfgang Böhme (Karlsruhe: Tron KG., 1982), pp. 65-66.

6 V. 306-307

7 J. W. Goethe, Goethes Werke: Hamburger Ausgabe, 9th. ed., 14 vols. (München: C.H. Beck, 1981), vol. 3: p. 470. [Henceforth referred to as HA.] Regarding the possible reading of Faust, and specifically the scene Nacht, as a 'Gelehrtensatire' see the following work: Alexander Košenina, Der gelehrte Narr: Gelehrtensatire seit der Aufklärung (Göttingen: Wallstein, 2003), pp. 227-229. Here Košenina clarifies that Goethe's detailed discussion of the historical views and problems pertaining to the various fields of knowledge (in the case of Faust) and philology (in case of Wager) lessens the satiric effect of the work. Košenina constantly refers to the treatment of the theme at hand as 'Gelehrtenkritik': 'Diese gelehrteste Gelehrtenkritik mindert die satirische Wirkung'. Ibid., p. 228.

8 Trunz suggests that Faust $I$ is constituted of two main thematic lines, which are 'Gretchentragödie’ and ‘Gelehrtentragödie’. HA, vol. 3: p. 470. 
Erkenntnis über sich hinauszugelangen'. ${ }^{9}$ Here, we approach and analyze Goethe's Faust in respect to one thematic aspect - the longing to go beyond the existing definitions of self through self-knowledge and knowledge of the world. Yet first we must define the form of knowledge in question.

\section{I.1.2 Knowledge and Self-knowledge in Faust}

To explain the relation between knowledge and self-knowledge in Goethe's Faust, it is first necessary to understand the author's view of knowledge in relation to the human being.

The most important feature of Goethe's theory of knowledge is that it views truth, the object of pursuit, as identical with the divine. The relation between the divine source of intelligible content in the world, on the one hand, and the world itself and the seeker of knowledge, on the other hand, must be considered in this light. This does not mean that Goethe considers the natural world to be devoid of intelligible divine content. On the contrary, as the following quote from his Versuch einer Witterungslehre explains - and as I will further demonstrate in the course of this study -, the One and the many are intimately related. The former is perceivable in the latter in an indirect manner:

Das Wahre mit dem Göttlichen identisch, läßt sich niemals von uns direkt erkennen, wir schauen es nur im Abglanz, im Beispiel, Symbol, in einzelnen und verwandten Erscheinungen; wir werden es gewahr als unbegreifliches Leben und können dem Wunsch nicht entsagen, es dennoch zu begreifen. ${ }^{10}$

Bearing this fact in mind, we now turn to Goethe's pursuit of knowledge of nature.

After controversial debates in the late nineteenth century regarding the significance of Goethe's contribution to science, contemporary scholarship sees the writer of Faust as a researcher of natural sciences as well as a poet with a horizon of knowledge encompassing meteorology, physics, geology, morphology of plants and comparative osteology. ${ }^{11}$

9 J. W. Goethe, Faust: der Tragödie erster und zweiter Teil: Urfaust, ed. Erich Trunz (München: Beck, 1991), p. 477.

10 FA I, 25: p. 274 (my emphasis).

11 See for instance here a short history of alteration of evaluations of Goethe's scientific achievements and specifically methodology in: D. Peter Smith, 'Was die Welt im Innersten zusammenhält: Scientific Themes in Goethe's Faust', in A Companion to Goethe's Faust: Part 1 and 2, ed. Paul Bishop (Columbia: Camden House, 2006), pp. 194-195. 
Philological facts reflect the difficulties that Goethe faced in his pursuit of the natural sciences. He struggled to earn the recognition he expected for contributions such as his Farbenlehre and his findings in the field of comparative osteology. As Dane demonstrates, on multiple occasions Goethe expressed his discontent '[d]aß seine naturwissenschaftlichen Forschungen in der zeitgenössischen Öffentlichkeit nicht die Wertschätzung erfuhren, die Goethe sich gewünscht hatte, wußte er und bedauerte es außerordentlich' ${ }^{12}$ Considering the circumstances ${ }^{13}$ in which Goethe persistently carried out his research in the natural sciences, we ask ourselves 'warum hat Goethe sich nicht auf die so genannte schöne Literatur beschränkt?'14 The answer is simple: Goethe did not believe, as modern science does, in clearly delineated borders between different fields of knowledge. More importantly, he did not recognize natural science as fundamentally distinct from culture and humanities. ${ }^{15}$ As macrocosm and microcosm, natural science and humanities are intimately related, Goethe thought. ${ }^{16}$ In his letter to Zelter on January 29, 1831, Goethe writes, 'Hätt ich mich mit den Naturwissenschaften nicht abgegeben, so hätt ich die Menschen nie kennen lernen.' ${ }^{17}$ As Dane explains, 'Der Wunsch nach Menschenkenntnis, Wissen über den Menschen - darin liegt eine Motivation für seine Naturerforschung. ${ }^{, 18}$ As he makes clear in his letter to Zelter, Goethe viewed knowledge of the natural world as a prerequisite for anthropological knowledge. Dane emphasizes that this view was one of the main motivations for Goethe's pursuit of knowledge of nature.

For Goethe, humanities, natural science and literary work were deeply related. In his speech Zum Shakespears [sic] Tag (1771), Goethe explains how he finds in the works of the English poet a sort of knowledge of nature that had been neglected by many great philosophers. This knowledge of nature, Goethe argues, manifests in the plots and characters of Shakespeare's dramas. ${ }^{19}$ In

12 Gesa Dane, 'Unerhörte Begebenheiten. Was lesen wir, wenn wir Goethe lesen?', in 'Göthe ist schon mehrere Tage hier, warum weiß Gott und Göthe' Vorträge zur Ausstellung 'Der gute Kopf leuchtet überall hervor' Goethe, Gottingen und die Wissenschaften, ed. Elmar Mittler (Göttingen: Niedersächs. Staats- und Univ.-Bibliothek, 2000), p. 14.

13 Schiller remarked that, if Goethe had published his research under a pseudonym, he would have had more success reaching his readers. See Schiller's Letter to Goethe 23 Nov. 1795 explained and cited in: ibid., p. $12 \& 14$.

14 Ibid., p. 15.

15 Ibid., p. 12.

16 Ibid., p. 17.

17 FA II, 2: p. 363.

18 Dane, 'Unerhörte Begebenheiten. Was lesen wir, wenn wir Goethe lesen?', p. 16.

19 FA I, 18: pp. 11-12. 
Farbenlehre, Goethe opines that the scientist should abandon an essentialist approach toward light and colors; he supports this methodological claim with an example taken from the realm of anthropology - a field that he viewed as inseparable from the literary field of narratology, let us recall.

Denn eigentlich unternehmen wir umsonst, das Wesen eines Dinges auszudrücken. Wirkungen werden wir gewahr, und eine vollständige Geschichte dieser Wirkungen umfaßte wohl allenfalls das Wesen jenes Dinges. Vergebens bemühen wir uns, den Charakter eines Menschen zu schildern; man stelle dagegen seine Handlungen, seine Taten zusammen, und ein Bild des Charakters wird uns entgegentreten.

Die Farben sind Taten des Lichtes, Taten und Leiden. ${ }^{20}$

Here, we observe that the relation between literature and knowledge of nature is reciprocal in Goethe's view. ${ }^{21}$ In the speech Zum Shakespears Tag and in the passage above, Goethe shows anthropology and poetics to cast light on scientific horizons. Now we can inquire about the relation between knowledge and selfknowledge. In Bedeutende Fördernis durch ein einziges geistreiches Wort, Goethe reflects on the famous injunction to know thyself:

Hiebei bekenn ich, daß mir von jeher die große und so bedeutend klingende Aufgabe: erkenne dich selbst, immer verdächtig vorkam, als eine List geheim verbündeter Priester, die den Menschen durch unerreichbare Forderungen verwirren und von der Tätigkeit gegen die Außenwelt zu einer inneren falschen Beschaulichkeit verleiten wollten. Der Mensch kennt nur sich selbst, insofern er die Welt kennt, die er nur in sich und sich nur in ihr gewahr wird. Jeder neue Gegenstand, wohl beschaut, schließt ein neues Organ in uns auf. ${ }^{22}$

This quote articulates the view that self-knowledge and knowledge of the world are interconnected. Pursuing knowledge of the world, Goethe argues, has an additional purpose: it creates a space within which self-knowledge can unfold and grow.

The author's view of the interrelation of knowledge of the world and selfknowledge can be traced to verses 354-357 of Faust's opening monologue in the scene Nacht. In these verses, Faust expresses discontent with knowledge that is abstracted from the real world and its intersubjective, social and communicative aspects. His own knowledge, he admits, though vast by some measures, is bereft of worldly intelligence. Here, Faust gestures toward the inner

20 FA I, 23/1: p. 12.

21 See also: Dane, 'Literatur zwischen Natur- und Kunstlehre: Goethes Erzählung Der Mann von funfzig Jahren'. Here, Dane expounds on the presence of the reciprocal relation between natural science and literary work in Goethe's Der Mann von funfzig [sic] Jahren.

22 FA I, 24: p. 595-596. 
relation between knowledge of the world and self-knowledge that we know to be such an essential part of Goethe's own world-view. ${ }^{23}$

Bilde mir nicht ein was rechts zu wissen,

Bilde mir nicht ein ich könnte was lehren

Die Menschen zu bessern und zu bekehren. ${ }^{24}$

Throughout this study, we will return again and again to how a character's understanding of knowledge informs his or her ethical personality and how characters change their conceptions of knowledge in the course of the drama. There is a noticeable difference between an abstract conception of knowledge that is irrelevant to the ethical aspect of a person's life and the ethically embedded kind of knowledge which Faust strives for and which he introduces in his opening monologue.

In Faust, knowledge (in its different fields) is present as a literary element in the drama. In other words, the work 'never propagandizes but instead reflects the intricate mystery of nature and the complexity of the human relation with the material realm'. ${ }^{25}$ Furthermore, the drama contains references to the scientific scene of Goethe's time and problematizes various assumptions and theories. The debates between Anaxagoras and Thales are a good example of this aspect of the literary work. ${ }^{26}$

Though alchemy is not among the four branches of knowledge in the opening of the scene Nacht, multiple allusions to alchemy can be found in the text. As the eighth book of the second part of Dichtung und Wahrheit informs us, the young Goethe invested a certain amount of time in reading sources of alchemy and conducting experiments. ${ }^{27}$ Dorothea Kuhn situates Goethe's interest in alchemy within his larger world-view:

Die Magia naturalis entsprach in ihrer Einheit, die sich bis ins Theologische erstreckte, einer Einheit suchenden Grundveranlagung Goethes, und so sind in seine Naturanschauung unauslöslich Elemente dieses merkwürdigen Kosmos eingegangen. ${ }^{28}$

23 See also Gaier's comments on the first scene of Faust I and the historical relevance of knowledge and anthropology here: Ulrich Gaier, Johann Wolfgang Goethe Faust-Dichtungen, 3 vols. (Stuttgart: Reclam, 1999), vol. 2: p. 83.

24 V. 371-374.

25 Smith, 'Was die Welt im Innersten zusammenhält: Scientific Themes in Goethe's Faust', p. 196.

26 See Schöne's comments in FK, pp. 506-507; p. 768.

27 FA I, 14: pp. 376-378.

28 Dorothea Kuhn, Typus und Metamorphose: Goethe-Studie (Marbach am Neckar: Deutsche Schillergesellschaft, 1988), p. 108 (my emphasis). 
Studies have explored Goethe's acquaintance with alchemy in great depth, and Goethe's knowledge of the subject appears in many of his works - not least of all, Faust. The young Goethe aspired to study alchemy in Frankfurt in 1768 and 1769 influenced by his friendship with Susanne Katharina von Klettenberg. ${ }^{29}$ Alchemy, in its own way, paints a picture of the cosmos in which the human being and nature - the microcosm and the macrocosm - are deeply interrelated and in which boundaries between disciplines of knowledge are softened.

In the case of alchemy, Faust explicitly articulates his views in conversation with Wagner in the scene Osterspaziergang. In the context of discussing his father, who helped the people during an outbreak of the plague, Faust portrays alchemy as an illegitimate manner of pursuit of knowledge of the natural world.

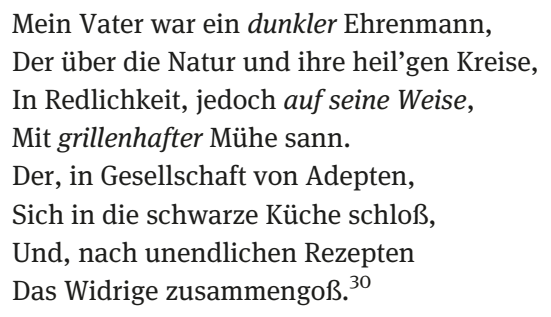

In verse 1034, Faust expresses his disagreement with his father's approach through his ironic tone: 'auf seine Weise'. Faust denigrates his father's work as unoriginal and describes his father's dabbling in alchemical experiments as nothing more than reproduction of recipes of the past, carried out 'nach unendlichen Rezepten'. Furthermore, as Schöne explains, referring to Johann Heinrich Campe's Wörterbuch der Deutschen Sprache, the word 'grillenhaft', found in verse 1037, expresses 'thoughts and impressions that lack any support but bring about unrest' and may be translated into English as 'capricious' as opposed to 'systematic'. 31

Astrology also comes under criticism in Faust. In Faust II, we learn the true source of an astrologist's insights. In the ironic scene Kaiserliche Pfalz Saal des

29 Ibid., p. 197.

30 V. 1034-1041 (my emphasis). Also see Schöne's detailed explanation of the terms and codes of alchemy in the verses 1038-1049 in FK, p. 239.

31 See the original comment of Schöne in his comments on Faust p. 236 and compare to: Johann Heinrich Campe, Wörterbuch der Deutschen Sprache, ed. Johann Heinrich Campe, 5 vols. (Braunschweig: Schulbuchhandlung, 1808), p. 455. 'Seltsame herbeigesuchte Gedanken und Vorstellungen ohne Grund, und die nur Unruhe verursachen.' 
Thrones, the astrologist, seemingly hypnotized by Mephisto, inanely echoes whatever Mephisto whispers in his ear. ${ }^{32}$ A passage from Goethe's Versuch einer Witterungslehre comes to mind:

[W]ir wagten den Mond, die Mitplaneten und ihre Monde, zuletzt die gegeneinander unbeweglichen Gestirne als mitwirkend zu betrachten, und der Mensch, der alles notwendig auf sich bezieht, unterläßt nicht, sich mit dem Wahne zu schmeicheln, daß wirklich das All, dessen Teil er freilich ausmacht, auch einen besondern merklichen Einfluß auf ihn ausübe ${ }^{33}$

In each of the instances mentioned thus far, we find critiques of certain kinds of knowledge with respect to the human realm. In particular, as we see in the quote above, Goethe criticizes astrology as a faulty manner of understanding the relation between the human and cosmic realms - one in which the human being, acting irrationally, follows his disposition to reconstruct everything in relation to himself, as though the cosmos exerted a special influence on him.

In his comments on Faust, Schöne writes, 'Die Möglichkeit einer umgreifenden "Weltformel" freilich hat Goethe lebenslang beschäftigt." ${ }^{34}$ Faust shares his author's ambition and likewise views universal knowledge as encompassing the realms of cosmology and anthropology. For Goethe and Faust alike, the relation between self-knowledge ('know thyself') and knowledge of the world is not confined to a specific field of knowledge - the unity of knowledge erases the modern scientist's arbitrary boundaries.

This broad and philosophical view of knowledge is as old as the ancient Greek philosophers. But it also has a place in literary texts - not only philosophical treatises. As I demonstrated earlier, knowledge in Faust extends itself to the life of the seeker and other human agents; crucially, moreover, as I argue later, the manner of pursuit of knowledge informs how the seeker of knowledge conceives the relation between body and soul. Assessing Goethe's view of knowledge, however, is only the first step toward exploring possible ways in which Faust poetically discusses the pursuit of knowledge as an indispensable part of human life and, specifically for the purposes of this study, informs our understanding of the relationship between the body and soul.

In comparing Faust with Hāfiz’s Divan from the fourteenth century, a question arises: to what extent are the natural sciences, based on experiment in the modern sense, present in Faust? As I demonstrated in this section, Goethe did

32 V. 4955-4970.

33 FA I, 25: pp. 275-276.

34 FK, p. 214. 
not view knowledge as modern science does. And if any doubt about that point remains, consider that Goethe disparaged the instruments of contemporary science as 'das größte Unheil der neuern Physik'. ${ }^{35}$

Turning now toward the Faust text itself, we find that 'knowledge' in the modern experimental sense does not appear. Wagner's invention of a machine that would make sexual intercourse superfluous for reproduction is the closest we come to a modern experimental view of knowledge. Yet the motivation for this enterprise has to do with Wagner's evaluation of natural reproduction, a view that reflects his own idiosyncratic anthropological standpoint and that appears far removed from the modern consensus. Mayer correctly describes Wagner as follows:

Ein gütiger, dankbarer, nicht sehr vitaler Mensch. In der Menge fühlt er kaum sich wohl, die Natur betrachtet er ohne Geduld, der Zeugungsvorgang ist ihm tierisch, so daß sich die Wissenschaft die Aufgabe stellen muß, Fortpflanzung zu humanisieren. ${ }^{36}$

Furthermore, the method that Wagner practices is not what the modern science would consider 'scientific experiment,' despite its appearance as such - 'äußere Anschein trügt'. ${ }^{37}$ Mayer explains:

\footnotetext{
Wagner verhält sich durchaus nicht fragend und in wissenschaftlicher Neugier experimentierend. Er besitzt Gewißheiten. Die verdankt er den überlieferten Rezepten. Auch hier stellt er seine Quellen nicht kritisch in Frage. Da er alles gelesen hat, weiß er jetzt, auf welche Mischungen es bei Menschenschöpfung ankommen muß. ${ }^{38}$
}

As I demonstrated above, the form of knowledge whose pursuit is dramatized in Goethe's Faust is a unified knowledge that is intrinsically connected to selfknowledge and that hearkens back to ancient Greek philosophy. Defined in this way, the pursuit of knowledge and self-knowledge in Goethe's Faust invites comparison to the Divan of Hāfiz.

35 See Goethe's letter to Zelter of June 22, 1808, explained and cited in: Kuhn, Typus und Metamorphose: Goethe-Studie, pp. 90-91.

36 Hans Mayer, 'Der Famulus Wagner und die moderne Wissenschaft', in Gestaltungsgeschichte und Gesellschaftsgeschichte, ed. Helmut Kreuzer, Gestaltungsgeschichte und Gesellschaftsgeschichte: Literatur-, Kunst- und Musikwissenschaftliche Studien (Stuttgart: Metzler, 1969), p. 177.

37 Ibid., p. 192.

38 Ibid. See also in: Smith, 'Was die Welt im Innersten zusammenhält: Scientific Themes in Goethe's Faust', p. 198. 


\section{I.1.3 Knowledge in the Divan of Ḥāfiz}

\section{I.1.3.1 Terms that Represent Knowledge in the Divan}

In the Divan of Hāfiz, we find several terms that all translate, roughly, as 'knowledge,' but with important semantic differences. The Persian word dāniš and the Arabic word 'ilm both translate to 'knowledge' in a general sense. Since Arabic was the language of scholarly writing and teaching of the time, Haaffiz’s poetry uses terms with Arabic roots to differentiate various aspects of knowledge in a more specialized context. Hikmat ('wisdom') and hakim ('a wise person') are used frequently in the Divan. ${ }^{39}$ In addition, the word 'ärif ('gnostic' - a seeker of knowledge learned in Sufism, but not necessarily a follower of any particular school) appears thirteen times in the Divan. ${ }^{40}$ Sufism as a form of attaining knowledge of the divine and its relation to the world, permeates the Divan and forms the cultural backdrop to the text's representation of the pursuit of knowledge - the word 'Sufi' appears thirty-five times in the Divan. ${ }^{41}$ For further elucidation concerning the multiplicity of terms related to 'knowledge' that were used in Hāfiz’s time, we turn to an encyclopedia written in Shiraz by one of Haăfiz̧'s contemporaries, the renowned polymath Šams ud-Dīn Āmulī.

\section{I.1.3.2 Hikmat and Sufism in Šams ud-Dīn Āmulī’s Encyclopedia}

Šams ud-Dīn Āmulī (d. in Shiraz 753 H/1352 CE) was the writer of the encyclopedia Nafā'is ul-funūn fì 'arā'is al-'uyūn. After years of teaching in the Sulțānīya Madrasa, he immigrated to Shiraz due to increasing instabilities in Il-hānīs' rule over Āzarbāyǧān. He lived, taught, and finished Nafā'is ul-funūn in Shiraz during the short period of the relatively peaceful reign of Šāh Šayh Abū Ishāa (ruled ca. 1342-1353) of the İynğū dynasty (ca. 1325-1353), ${ }^{42}$ who was in fact the royal patron of Hāfiz.. ${ }^{43}$ In Āmulī’s definition, hikmat consists of:

39 The word hikmat ('wisdom') appears seven times; hakīm ('a wise person') eight times; and hakīmāna ('wise' adj. and 'wisely') once in the Divan: Mahīndoht Ședdīqīyān and A. Mīr'ābedīnī, Farhang-e vāženāme-ye Hāafiz (Tehran: Amīr Kabīr, 1366/1987), p. 378. See: Ahūr’s comments regarding different aspects of the term hikmat and a list of couplets in which this term appears: Parvīz Ahūr, Kelk-e hīyālangīz, 4 vols. (Tehran: Asāṭīr, 1382/2004), pp. 805-808.

40 Ședdīīìān and Mīr'ābedīnī, Farhang-e vāženāme-ye Hāâfiz, p. 801.

41 Ibid., p. 777.

42 John Limbert, 'Inju Dynasty’ In Encyclopædia Iranica, Ehsan Yarshater, XIII, pp. 143-147, (New York: Encyclopædia Iranica Foundation, 2006), p. 143.

43 Šams ud-Dīn Āmulī, Nafā'is ul-funūn fì 'arā'is ul-'uyūn comment and research Abū 'l-Hasan Ša'rānī, 3 vols. (Tehran: Eslāmīye, 1381/2002), p. 14. vol. 1. Introduction by Abū 'l-Ḥasan Ša'rānī 
1. Practical hikmat (hikmat-i 'amalī), which in turn consists of ethics, politics and household management (oikovouía).

2. Theoretical hikmat (hikmat-i nazarī):

a. Logic: İsāg̀ūğì (Isagoge of Porphyry), Qāțiḡūrìyās (Aristotle’s Categories), Bārīrimīnās (Aristotle's Peri Hermeneias), Sūlūǧimūs (Syllogism), Anūlūțīqā (Analytica) on art of argumentation, Țūbīqā (Aristotle's Topics) on disputation, Sūfasțīqa (Aristotle's Sophistical Refutations) on fallacies, Rìțūrīqā on rhetoric, Abūțīqa [Aristotle’s Poetics] on poetics.

b. First Philosophy (falsafa-yi ūlā): Metaphysics

c. Theology: including knowledge of the Necessary Existent; knowledge of praise of its magnificence; knowledge of the manner of emanation of its influences and care; and knowledge of intellects and their influence in the realm of soul and matter. This, according to Âmulī, can be pursued in nature and the divine realm based on the seeker's perspective.

d. Knowledge of natural objects: the realm of generation, decay and minerals.

3. Mathematics: including geometry, arithmetic, astronomy and music - in this exact order.

4. Secondary nature: a. medicine, diagnosis and pharmacy; b. alchemy, the occult knowledge and knowledge of talisman. ${ }^{44}$

As we see, hikmat covers a wide range of knowledge, and one who masters it all rightly deserves to be called a polymath (hakim). It is clear that the definitions of knowledge above were influenced by ancient Greek philosophy and science. In other words, hikmat covers the full spectrum of knowledge encompassed by philosophy in the ancient Greek sense of the term. More importantly, for our present purposes, hikmat denotes the unity of the branches of knowledge listed above by Āmulī.

Āmulī's writings also provide valuable information regarding the level of education expected of a man of letters. Such a person was expected to be proficient in rhetoric, astronomy, music, chess and backgammon, and would have been able to converse knowledgeably about each of these subjects. ${ }^{45}$ The learned person should practice poetry, but not too much. It was a temptation to be resisted, given the adoration that elites and masses alike accorded to poets. Āmulī warns, lest he be remembered merely as a poet, and not as a hakìm. Āmulī offers Nāṣir Husrau, Anvarī and Sarāğ ud-Dīn Qumrī as cautionary examples: 'each one [of these men] was one of a kind in sciences, accomplishments, and author of unique books, but as they have devoted much time to poetry, they were categorized as poets and not men of other sciences. ${ }^{46}$

44 Ibid., vol. 1: pp. 19-20 (my summary and translation).

45 Ibid., vol. 2: p. 139.

46 Ibid., pp. 138-139 (my translation). 
Âmulī's definition of the path of the wayfarer in Sufism, too, bears a close resemblance to Platonic views concerning the abstraction of the bodily and natural realms from the sublime, extramundane truth that is identical with the divine. The path of a Sufi, according to Āmulī, is one of self-mortification and selfpurification pursued with the aim of ascending to the transcendent truth (haqq ta' $\bar{a} l \bar{a})$. To this end, fasting, sleep deprivation and meditation in solitude and darkness are prescribed as a way to weaken the outward senses and open the inward ones. ${ }^{47}$ At the core of Sufism, Âmuli explains, lies knowledge of the truth ('ilm-i haqīqat), ${ }^{48}$ defined as re-cognizing the simple known (ma'lūm-i muğmal) in the multiplicity (șuvar-i tafāṣil). ${ }^{49}$ To explain the meaning of the lower-soul (nafs), the soul, and the hierarchy that links them - all part of knowledge of the truth -, Āmuli constantly appeals to Neoplatonic views of emanation. ${ }^{50}$

The influence of Platonic and Alexandrian philosophy, particularly as they explain the relation between the transcendent divine truth and the natural, human realms, is constantly present in Sufi works from the twelfth century. Later in this chapter, I briefly discuss how Greek philosophy was introduced to the Islamic world and I point out how Platonic views on love found their way into hagiographic Sufi books. ${ }^{51}$

Haafiż’s intellectual and poetic dialogue with Sufi views will be an important part of our work in the following chapters. In the next sub-section, I give a brief account of the presence of various branches of hikmat in the Divan in order to cast light on the poet's vast erudition.

\section{I.1.3.3 Branches of hikmat in the Divan of Haăfiz}

In the Divan, Hāfiz mentions several branches of hikmat that Āmuli defines in Nafä'is ul-funūn. In one poem of the Divan, the poet flaunts his knowledge of logical terminology ${ }^{52}$ : 'O wine-boy, how long the delay in circulating the cup? | When the round falls to lovers it must be uninterrupted. ${ }^{53}$ In Arabic-Persian

47 Ibid., vol. 2: p. 5.

48 Ibid., vol. 1: p. 18.

49 Ibid., vol. 2: p. 43.

50 Ibid., vol. 2: pp. 45-51.

51 See pp. 36-38 below.

52 'Abd ul-Ḥusaīn Zarrīnkūb, Az kūče-ye rendān (Tehran: Amīr Kabīr, 1382/2003), p. 62.

53 The Collected Lyrics of Háfiz of Shíráz, trans. Peter Avery (London: Archetype, 2007), [Henceforth cited as Avery, gazal, couplet, page number], CCLXXI, 7, p. 340 (my emphasis). Since Avery follows Hānlarī's edition of the Divan, the number of the gazal and the couplet are identical between the two: Hु̃āğa Šams ud-Dīn Muḥammad Ḥāfiz, Dìvān-e Hiāfiz ġazalìyāt, qașā'ed, mașnavìyāt, qața'āt va robā' ìyāt, ed. Parvīz Nātel Huānlarī, 2nd ed., 2 vols. (Tehran: 
logic terminology, the logical concept of a 'vicious circle' translates literally as 'uninterrupted circulation' ('daur-i tasalsul'). In the poem above, Hāfiz decontextualizes this term as though he were addressing fellow scholars. He invites them to experience the term in the context of bacchanalian lyrical poetry. ${ }^{54}$

The poems of the Divan also reflect that the poet was an expert minstrel with vast knowledge of Iranian modal music (mūsīqī-yi dastgāhì). ${ }^{55}$ One of the branches of hikmat, music appears in the Divan through the poet's naming of different gūša (melodic types) and dastgāhs (organized yet modifiable musical compositions made of coherent gūšas). ${ }^{56}$ Knowledge of Persian music is indeed a prerequisite for appreciating the many verses in the Divan in which the emotional mode of the musical motif or composition is referred to. And another level of meaning becomes accessible if one reads the names of these musical units literally. Bearing in mind the poet's expertise as a minstrel, consider the following verses from the Divan: 'Love's murmur, into Hejāz and 'Erāk, casteth | The melody of the strain of ghazals of Ḥāfiẓ of Shīrāz. ${ }^{57}$ Here, Hiǧāz and 'Irāq are musical terms denoting the melodic peak (auğ) of a given musical composition, but if we take the terms literally, they also convey the metaphorical 'peaks' that the poet's fame reached during his lifetime. ${ }^{58}$

Pythagoras's conviction that the movement of the heavenly bodies creates a cosmic music is also reflected in Hāfiz's poetry. In the following cases of

$\left.\mathrm{H}^{\mathrm{V}} \bar{a} \mathbf{r a z m i ̄}, 1362 / 1984\right)$. [Henceforth referred to as Hānlarī, number of the ġazal, couplet]. The citations and references to the Divan will be to Haānlarì's edition, unless mentioned otherwise.

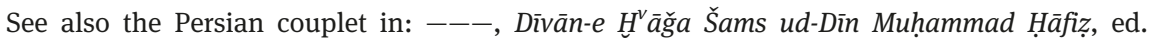
Qāsim Ġanī; Muḥammad Qazvīnī (Tehran: Zawwār, 1320/1941). [Henceforth referred to as Qazvīnī \& Ġanī, number of the ġazal, couplet], 276, 7.

54 Compare to: Muhammad Mu'īn, Ḥāfiz-e šìrīnsohan (Tehran: Bongāh-e Bāzargānī-ye Parvīn, 1319/1940), p. 88.

55 See also: ibid., pp. 93-94.

56 See: Jean During, 'Dastgāh’ In Encyclopædia Iranica, Ehsan Yarshater, VII, pp. 104-105, (Costa Mesa, California: Mazda, 1996).

57 Khwāja Šamsu-d-Dīn Muhammad Ḥāfiz, The Dīvān: Written in the Fourteenth Century by Khwāja Shamsu-d-Dīn Muhammad-i Hẹäfiz-i Shīrāzì otherwise known as Lisānu-l-Ghaib and $\overline{T a}$ rjumānu-l-Asrār. Translated for the first time out of the Persian into English prose, with critical and explanatory remarks, with an introductory preface, with a note on Șüfi,ism, and with a life of the author by H. Wilberforce Clarke., trans. H. Wilberforce Clarke (London: Octagon Press, 1974), 299, 7, p. 521. [Henceforth referred to as Clarke, ǵazal, couplet, page number.] Fikand, zimzima-yi 'išq dar Ḥiğāz u 'Irāq / Navā-yi bāng-i g gazalhā-yi Ḥāfiz az Šīrāz. In: Qazvīnī \& Ġanī, 259,7 .

58 Note that Hiğāz also refers to an area including Mecca and Medina, which are far from Shiraz and 'Irāq (Here 'Irāq-i 'Ağam or Persian Iraq is meant - an area that included Isfahan, Ray, Hamadān.) 
hyperbole, the Pythagorean view is turned upside down. Marveling at the poet's mastery of the form of $\dot{g} a z a l$ and art of minstrelsy, the heavenly bodies themselves begin to dance:

The song is sung and the pearl is strung;

Come hither, oh Hafiz, and sing again!

And the listening Heaven above thee hung

Shall loose o'er thy verse Pleiades' chain. ${ }^{59}$

In another instance, we read the following: 'On the sky, -what if, of Ḥāfiz’s's utterances | Zuhra's [Venus] singing should bring to dancing the Masīhā (Christ). ${ }^{60}$

Joachim Wohlleben offers a helpful commentary on the above verse: 'Nach muslimischer Lehre ist Jesus nicht gestorben, sondern als besonders reiner Mensch in den Himmel erhoben worden, und zwar in die vierte Himmelssphäre, in der auch Sohre weilt. ${ }^{, 61}$ Wohlleben's comment is correct in so far as it describes the ascent of Christ; however, Venus is not in the fourth heavenly sphere, but rather in the third. The fourth sphere houses the sun, associated with Christ. Later in this study I address the relation between the sun and Christ in greater detail ${ }^{62}$; for the time being, it suffices to note the poet's knowledge of the Ptolemaic astronomical arrangement of the heavenly spheres and the intimate connection, made apparent in music, between the realm of anthropology and the heavenly spheres.

The Divan also displays the poet's knowledge of astrology and astronomy. In several poems, we find verses in which different constellations, conjunctions and planets act as metaphors corresponding to their respective astrological significance. When describing the beauty of his beloved's eyebrow, the poet cannot help but recall the bow of Jupiter; and he describes her gaze as dominating

59 Ḥāfiz, The Hafez Poems of Gertrude Bell, trans. Gertrude Lowthian Bell (Bethesda, Maryland: Iranbooks, 1995), 5, p. 71. See also this couplet's translation in: Clarke, 8, 7, p. 43; Hafiz, Die Ghaselen des Hafiz: Neu in deutsche Prosa übersetzt mit Einleitung und Lesehilfen, trans. Joachim Wohlleben (Würzburg: Königshausen \& Neumann, 2004). [Henceforth the citations from Wohlleben's translation are referred to as Wohlleben, gंazal, couplet, page.], 3, 9, p. 51. Consider that Wohlleben follows Hānlarī's edition of the Divan and therefore the number of gazals and couplets are identical with that edition. The Persian couplet in my transcription: ġazal guftì u dur sufti bìyā u huš̌ biȟvān Ḥāfiz / Ki bar naẓm-i tu afšānad falak 'iqd-i șuraīyā rā.

60 Clarke, 9, 9, p. 45. Dar āsimān na-'ağab gar ba gufta-yi Ḥāfiz / Surūd-i Zuhra ba raqș āvarad Masīhā rā. Transcription according to Qazvīnī \& Ġanī, 4, 8.

61 See Wohlleben's footnote on p. 52.

62 See this work p. 78. 
the lion of the sun (the astrological term for the sun when it enters the constellation of Leo and reaches the peak of its power). ${ }^{63}$

Describing auspicious events, Hāfiz uses astrological conjunctions that signify luck and happiness (such as the moon and Jupiter) as a literary instrument. The comparison underscores the rarity of the event and thus conveys how precious the moment is for the poet: 'I asked: "When will the master be going to the bridal chamber?" | He answered: "The time when Jupiter and the moon are in conjunction.",64

Despite his use of astrological terms as a poetic device, the poet was critical of astrology outside of the poetic sphere. Viewing astrology as superstition, he strongly disputed that the planets and their movements influence human life, and its fortunes and misfortunes: 'Catch hold of the curl of the moon-cheeked one and do not repeat the fable. I That good luck and ill are from the effect of Venus and Saturn'. ${ }^{65}$ Ganì demonstrates that superstitions were strongly present not only among the masses, but also among the elites; political astronomy played a major role in the lives of educated kings, such as Šāh Šayh. ${ }^{66}$ After his great defeat at the hands of Amīr Mubāriz ud-Dīn, he openly admitted that his dependence on astrology compromised his decisions on important matters and blinded him to the facts. ${ }^{67}$

Medicine is another branch of hikmat that appears in the Divan. ${ }^{68}$ In one poem, the poet displays his erudition by mentioning the names of Ibn Sīnā's two major books: Qānūn (The Canon of Medicine) and Šifā' (The Book of Healing on philosophy, logic, and natural sciences). Yet the poet plays on words, inviting us to read the titles literally (qānūn: canon, law; and šifä') cure, healing):

63 Zarrīnkūb, Az kūče-ye rendān, p. 62. See the following verses: Avery, CCCXCI, 5, p. 476; CCIX, 9, p. 273 see also Hammer-Purgstall's comment on the later couplet in: Mohammed Schamsed-din Hafis, Der Diwan, trans. Joseph von Hammer-Purgstall (Hildesheim New York: Georg Olms Verlag, 1973). [Henceforth the citations from Purgstall's translation are from this source] vol. 1: XCVI, pp. 345-346.

64 Avery, CXCIII, 8, p. 253. The Persian couplet is the following: Guftam ki hn ${ }^{v} \bar{a}$ ğa kiy ba sar-i hiğla mīravad | Guft ān zamān ki muštarī u mah qarān kunand

65 Avery, XLVI, 6, p. 79. The Persian couplet is the following: Bigìr țurra-yi mah čihra-ī u qișșa mahāan / Ki sa'd u naḥs zi ta'șìr-i Zuhra u Zuhạal ast

66 The ruler of Shiraz of İynğū dynasty 1342-1354 and Hāāiz’s patron.

67 Ġanī, Baḥs dar ās̄ār va afkār va aḥvāl-e Hāấz, pp. 182-183.

68 As an example of medicine in Divan see in the following article Mahdi Mohaqqeq's elaboration on the first couplet of the ġazal 422, in Mahdī Muhaqqiq, 'Gozāreš-e yekī az ta'bīrāt-e pezeškī dar še'r-e Ḥāfiẓ’, in Sohan-e ahl-e del: Mağmū'e-ye maqālāt (Tehran: UNESCO-Iran, 1371/1992), pp. 709-712. 
'Yesterday out of concern when he saw me, the physician said, | "Alas, your sickness is beyond the canon of healing.",69

In another instance, the poet refers to a standard medical procedure of the time - daily examination of the color of an unhealthy person's urine. He juxtaposes the function of the 'urine glass' used for this purpose to that of the wine glass in joyous times of drinking. 'He who has conferred the never-ending glass on me for the sake of keeping me alive, | Why does he keep taking my specimen glass to the doctor? ${ }^{70}$ In the Divan, terms of medicine are employed to convey poetic thoughts and emotions. Furthermore, they contribute phonetically to the musical flow of the work. The transliteration of the seventh couplet of the gazal 375 illustrates the phonetic function of the word 'glass' (šǐša): 'Ānki mudām šiša-am az pay-i 'aīš dāda ast / Šiša-am az či mībarad pǐši țabīb harzamān'. The letter šin, ringing three times in each line, evokes the sound of glasses of wine in bygone times of joy.

The terms of hikmat (discussed above) and Sufism (to which I turn in the following chapters) form a necessary backdrop for appreciating Hāfizian verses. For example, in the verses where the poet refers to two important and worldrenowned works of Ibn Sinnā, only the reader who is familiar with these works is able to access a layer of meaning of the poem in which it critiques a system of thought. That said, these terms are used in such a way that, even when the reader is unaware of their significance, the text still stands, and influences the reader with other poetic elements such as rhythm and onomatopoeic effect.

\section{I.1.3.4 Neoplatonism in the Cultural Horizon of Ḥāfiz}

As we have seen, hikmat and the different branches of knowledge in the cultural space of the Divan were deeply influenced by Greek philosophy. In this section, I briefly discuss the presence of the Greek philosophy and Neoplatonic views in this cultural space.

When Justinian closed the Academy in Athens in 529 CE, the Neoplatonists sought refuge in Ctesiphon, ${ }^{71}$ the capital city of the Sassanid Empire. There, under the rule of Husrau I (Husrau Anūšīravān), the environment was ripe for

69 Avery, LXXXII, 8, p. 122. See also: Mu'īn, Hāâfiz-e šìrinsohan, p. 90. The Persian couplet is the following: Dī guft țabīb az-sar-i ḥasrat ču ma-rā dìd / Hiyhāt ki ranğ-i tu zi qānūn-i šifā' raft. 70 Avery, CCCLXXV, 7, p. 458. See also this couplet in Wohlleben's translation: 'Derjenige, der mir ständig eine Flasche zur Erfrischung gebracht hat, | wieso trägt er (jetzt) immer wieder meine Flasche zum Arzt?' In: Wohlleben, 375, 7, p. 482.

71 Located 32 kilometers southeast of the modern city of Baghdad 
dialogue between the Zoroastrian theologians and their Neoplatonist guests. ${ }^{72}$ The use of Persian Zoroastrian terms in Greek philosophy, however, predates Plotinus's time; as early as the second century, Platonists such as Plutarch (ca. 45-120 CE) and his contemporary Atticus would make reference to the disorderly motion in the 'Indefinite Dyad' as 'Ahrīman' and described the Good as 'Ahūrā Mazdā.' Their use of these terms speaks to a longstanding tradition of intellectual exchange between Persia and Greece. ${ }^{73}$

Soon after the advent of Islam and capture of Mecca in 630 CE at the hands of Muslim armies, the era of Arab conquest began. ${ }^{74}$ In the years 632-650 CE, Muslims expanded their originally small territory to an empire. Yet their rulers lacked the knowledge and experience necessary for this sudden change. The challenges of ruling peoples of so many cultures and world-views became apparent with the uprisings during the time of the second Caliph 'Umar ibn al-Hुațāb; these problems 'were too complicated to be solved within the political and social framework of the existing system. ${ }^{75}$ Uprisings and conflicts continued as the Umayyad dynasty expanded the empire further. The system collapsed when a revolution engineered in Küfa, a city near the former capital of Ctesiphon, expanded to Marw and Hurāsān in the Northeast of today's Iran and, in $750 \mathrm{CE}$, finally put an end to the Umayyads' rule. This was the revolution that brought the 'Abbāsids to power.

The 'Abbāsids inherited a vast empire and all of the problems that came with it. They were aware of their need to educate themselves about how to govern such a vast empire. To attain the expertise they sought, the 'Abbāsids gave key positions and considerable power to Iranians. The most renowned Iranian families in the royal court were the Naubahtīs and the Barmakīs (Barmakids).

In response to social and political pressures caused by the empire's territorial expansions, al-Manșūr's rule (752-774 CE) saw a remarkable increase in patronage for translation and scholarship. ${ }^{76}$ Books of astronomy, medicine and other sciences were eagerly collected from all around the empire to be translated

72 Alexander Pletsch, 'Der Schein des Guten und das wahrhaft Gute bei Boethius', in Platonism im Orient und Okzident: Neuplatonische Denkstrukturen Im Judentum, Christentum und Islam, ed. Raif Georges Khoury (Heidelberg: Universitätsverlag Winter, 2005), p. 61.

73 John M. Dillon, The Middle Platonists: a Study of Platonism, 80 B.C. to A.D. 220 (London: Duckworth, 1977), pp. 208 \& 254.

74 John Bagot Glubb, The Great Arab Conquests (London: Hodder and Stoughton, 1963), p. 102.

75 M. A. Shaban, The 'Abbasid Revolution (Cambridge: Cambridge University Press, 1970), p. 14.

76 For an introduction to the pre-'Abbāsid translations from Greek see: Dimitri Gutas, Greek Thought, Arabic Culture: The Graeco-Arabic Translation Movement in Baghdad in Early 'Abbāsid Society (2nd-4th/8th-10th centuries) (London: Routledge, 1998), pp. 20-25. 
into Arabic. ${ }^{77}$ As a way to provide a methodological basis for theological debates, al-Mahdī, al-Manșūr's successor, commissioned the translation of Aristoteles's Topics from the Syriac translation of the work. ${ }^{78}$ In addition, Hārūn ar-Rašìd (r. 786-809), continuing his grandfather's legacy, added to the collection of works of Greek philosophy, and supported the translation of these sources. Al-Mas' $\bar{u}$ dì, a renowned historian of the tenth century, recounts the events in the time of Hārūn ar-Rašīd in his book The Meadows of Gold. He dedicates a special part to the intellectual activities of Yahyā ibn al-Hुālid al-Barmakī, ${ }^{79}$ the vizier of Hārūn ar-Rašìd. Here he describes how leaders of different schools of thought would gather in the vizier's own house ${ }^{80}$ :

Yahya [Yaḥyā ibn al-Ȟālid al-Barmakī], the son of Khalid ibn Barmak, an enlightened man, learned and fond of discussion and philosophical inquiry, gathered at his house for symposiums a number of famous controversialists chosen from among Muslim theologians, free-thinkers and divines of various sects. ${ }^{81}$

In one of these gatherings, the vizier suggested 'love' as the topic of the day's discussion. Mas'ūdi recounts the various views on the subject - the origin of love and its effect on lovers - advanced by the eminent guests in attendance. ${ }^{82}$ Remarkably, despite that these guests represented opposing schools of thought, they shared the view that likeness is the source of love. At the end of his

77 See also: ibid. In the first part, Gutas addresses the social and political backgrounds of the translation movement.

78 Compare to: ibid., p. 69.

79 In the Sassanid era, the ancestors of Barmakīs were both leaders and organizers of the temple of Nau Bahār in Balh. Goethe points to the influence of the Barmakīs in rule of 'Abbāsids and mentions their high status in the Sassanid era in his Noten und Abhandlungen zu besserem Verständnis of the West-östlicher Divan. Goethe's source, as Mommsen informs us, was Joseph von Hammer-Purgstall's Geschichte der schönen Redekünste Persiens mit einen Blüthenlese aus zweyhundert persischen Dichtern published in Wien, 1818. See: FA I, 3/1: p. 152; p. 161.; Katharina Mommsen, 'Die Barmekiden im West-östlichen Divan', Goethe: Jahrbuch der GoetheGesellschaft, no. 14/15 (1952/53), p. 281. See also: I Abbas, 'Barmakids' In Encyclopædia Iranica, Ehsan Yarshater, III, pp. 806-809, (New York: Bibliotheca Persica Press, 2000).

80 Ğ. Sattārī, 'Ešq-e șūfyāne (Tehran: Nashr-e Markaz, 1392/2013), pp. 271-272.

81 Mas'udi, The Meadows of Gold: The Abbasids, ed. Paul Lunde, trans. Paul Lunde (London: Routledge, 1989), p. 109. See also the original text in: 'Alī ibn al-Ḥusaīn al-Mas' 'ūdī, Murūğ ad dِahab wa ma'ādin al-ğawāhir, 7 vols. (Beirut: Manšūrāt al-Ǧāmi'a 'l-Lubnānīya, 1973), vol. 4: p. 236.

82 The diversity of views in this gathering was so important that the gathering had an expert ( $m u \dot{g})$ Magian to speak for their views as the thirteenth speaker. See: Mas'udi, The Meadows of Gold: The Abbasids, p. 111. 
account of the gathering, Mas'ūdī gives voice to the philosophical views of Galen and Plato ${ }^{83}$ :

According to Galen, sympathy is born between two intelligent beings because of the very similarity of their intelligences, but it cannot exist between two stupid people with limited minds, because of the stupidity which they share. 'Indeed,' he said, 'intelligence follows a regular path and it is possible for two beings following the same path to meet, while stupidity moves in a completely unpredictable way, which renders all encounters impossible. ${ }^{, 84}$

Mas'ūdī also quotes Plato ${ }^{85}$ : 'I do not know what love is. I only know that it is a divine madness, a passion which is neither to be praised, nor is worthy of blame. ${ }^{86}$ Mas 'ūdī's account of the gathering underscores the role of Greek philosophy in the intellectual milieu of the time; no serious discussion of theoretical and philosophical issues could ignore the views of Greek philosophers. In his book 'Ešq-e șūfyāne (Sufic Love), Ğalāl Sattārī demonstrates incontrovertibly the influence of Plato's views among the Sufis. He provides evidence that Plato's Phaedrus, alluded to by Mas'ūdī in the quote above, reappears in the writings of Šayh Aḥmad-i Ǧām-i Nāmiqī (1046-1141 CE). In his hagiographic work Tadkarat ul-aulìyā', 'Aț̣ār (1145/46-1221 CE) attributes Plato's words to Imam Ğa'far Șādiq, the sixth Imām of the Shia Muslims ${ }^{87}$ : 'and he [Ğa'far Ṣādiq] said, love is divine madness, not the object of praise or blame' ${ }^{88}$

The importance accorded to translations during this time was based on the view that knowledge is one and divine, regardless of the language in which it is produced: languages and cultures must be bridged in order to attain knowledge. $^{89}$ In his tenth-century work al-Fihrist, ${ }^{90}$ Ibn an-Nadim elaborates on the process of acquisition and assimilation of this wide spectrum of human knowledge. He begins the seventh chapter of al-Fihrist, dedicated exclusively to philosophy and philosophers, by recounting a myth that illustrates the universality and divine nature of knowledge. According to the myth, people were once

83 al-Mas'ū 'ī, Murūğ adِ-dahab wa ma'ādin al-ğawāhir, vol. 4: p. 243.

84 Mas'udi, The Meadows of Gold: The Abbasids, p. 113.

85 al-Mas'ū ūi, Murūğ ad-dahab wa ma'ādin al-ğawāhir, vol. 4: p. 245.

86 Mas'udi, The Meadows of Gold: The Abbasids, p. 114.

87 Sattārī, 'Ešq-e șūfyāne, p. 274.

88 Farīd ud-Dīn 'Aț̣āar, (Tehran: Ketābhāne-ye Markazī, 1336/1957), p. 24 (my translation).

89 Hayrettin Yücesoy, 'Translation as Self-Consciousness: Ancient Sciences, Antediluvian Wisdom, and the 'Abbāsid Translation Movement', Journal of World History, 20, no. 4 (2009), p. 524.

90 This source contains a bibliography of books and authors know to Ibn an-Nadim in the tenth century CE. 
governed by a council of seven wise men. When a prophet appeared among them, however, they refused to follow the wisdom of the seven wise ones. The seven wise ones went their separate ways, teaching wisdom to people in different lands across the world:

Among them [the seven] there was a wise man named Hermes. He was the most thoroughly intelligent, the most strikingly wise, and the most refined in discernment among them. He went to the land of Egypt, where he ruled over the inhabitants, making the land prosperous, improving the conditions of the people, and manifesting his wisdom among them. ${ }^{11}$

Later in the book, the writer of al-Fihrist suggests that the Caliph al-Ma'mūn's interest in Greek philosophy was not merely an interest in something foreign; rather, Aristotle, portrayed as the successor of Hermes, comes to al-Ma'mūn in a dream and awakens his interest. Ibn an-Nadim describes one reason why books of philosophy and ancient sciences were available in large numbers in Baghdad:

al-Ma'mūn saw in a dream the likeness of a man white in color, with a ruddy complexion broad forehead, joined eyebrows, bald head, bloodshot eyes, and good qualities sitting on his bed. Al-Ma'mūn related, 'It was as though I was in front of him, filled with fear of him. Then I said "Who are you?” He replied, “I am Aristotle.” Then I was delighted with him and said, "Oh sage, may I ask you a question?” He said "Ask it.” Then I asked, "What is good?" He replied, "What is good in the mind." I said again, "Then what is next?" He answered "What is good in the law." I said, "Then what next?" He replied "What is good with public.” I said, “Then what more?” He then answered, "More? There is no more.",92

Against this backdrop, Ibn an-Nadìm recounts al-Ma'mūn's correspondence with the Byzantine emperor:

[al-Ma'mūn] sent forth a group of men, among whom were al-Hajjāj ibn Mațar; ibn al-Bațrīq; Salmān, the director of the Bayt al-Hikmah; and others besides them. They brought the books from what they had found. Upon bringing them to him, he ordered them to translate [the manuscripts], so that they made the translation. ${ }^{93}$

Al-Fihrist provides a list of books by Plato, Euclid, Ptolemy, Hippocrates, Porphyry and Aristotle available in Bagdad at the time, as well as names of

91 The Fihrist of al-Nadim: a Tenth-century Survey of Muslim Culture, trans. Bayard Dodge, 2 vols., Records of civilization (New York: Columbia Univ. Press, 1970), vol. 2: Chapter VII, pp. 573-574.

92 Ibid., p. 583.

93 Ibid., p. 584. 
over fifty translators. ${ }^{94}$ Furthermore, Ibn an-Nadìm provides a detailed list of dialogues of Plato available in translation and the names of their translators and commentators. ${ }^{95}$

The Abbasid Caliph sought a rational mode of argumentation that would help Islamic theologians answer questions posed by a wide spectrum of theologies and philosophies. ${ }^{96}$ Islamic philosophy flourished in this abundance of textual sources. At the heart of the philosophic enterprise, Plato, Aristotle and Plotinus were given special attention.

Fārābī (870-950 CE) was one of the earliest influential Islamic Neoplatonists his epithet was The Second Teacher. ${ }^{97}$ He followed Plotinus's emanative system. His choices of terminology illustrate the central place of metaphysics in his thought. He describes the One as 'the First Existent,' an attribute that Plotinus also identified as the central characteristic of the One.

A group called Ihwān aṣ-Ṣafā (The Brethren of Purity) developed an 'ethico-spiritual' community for the élites that engaged deeply in philosophy, science and epistemological theory. Yet its ultimate purpose was not merely to acquire knowledge, but rather to build 'a refuge from the struggle that was raging among religious congregations' for those who believed in unity and brotherhood in the name of knowledge and philosophy. ${ }^{98}$ It is indisputable that the brotherhood's philosophy and cosmogony were systematically influenced by Plato, Aristotle, Plotinus and the Stoics. ${ }^{99}$

Ibn Sīnā (980-1037 CE) carried Fārābī's philosophy further by attributing to the One the predicate of 'Necessary Existent.' ${ }^{100}$ Ibn Sīnā was the first philosopher in the Islamic tradition to reconcile philosophy with Sufism. In his treatises Hayy ibn Yaqzān and Salāmān and Absāl, elements and terms from his and Fārābī's cosmological metaphysics appear in the Sufi context.

94 Ibid., pp. 586-590.

95 Ibid., pp. 592-593. For a detailed bibliography of translations of Greek works see: Gutas, Greek Thought, Arabic Culture: The Graeco-Arabic Translation Movement in Baghdad in Early 'Abbāsid Society (2nd-4th/8th-10th centuries), pp.193-196.

96 Compare to: R. B. Haris, 'Preface', in Neoplatonism and Islamic Thought, ed. Parviz Morewedge (Albany: State University of New York Press, 1992), p. viii.

97 The First Teacher, of course, was Aristotle.

98 Omar A. Farrukh, 'Ikhwān al-Ṣafā', in A History of Muslim Philosophy, ed. M. M. Sharif (Wiesbaden: Harrassowitz, 1963), p. 289.

99 See in ibid., pp. 294-298.

100 Parviz Morewedge, 'The Neoplatonic Structure of Some Islamic Mystical Doctrines', in Neoplatonism and Islamic Thought, ed. Parviz Morewedge, Studies in Neoplatonism, Ancient and Modern (Albany: State Univ. of New York Press, 1992), p. 55. 
Šahāb ud-Dīn Yahyā Suhravardī (548-569\1154-1191 CE) also followed Neoplatonic cosmogony and its hierarchy of existence. Furthermore, he offered a specific reading of the history of philosophy in which wisdom is seen as the path to truth, rather than mere 'rational systematization' ${ }^{101}$ In his view, similar to that articulated in al-Fihrist by Ibn an-Nadim, ${ }^{102}$ philosophy begins with Hermes and Agathodaimon and then goes in two directions: a Greek path tread by Asclepius, Pythagoras, Empedocles, Plato, Neoplatonists and Zū un-Nūn Mișrī; and an Iranian path that starts with Gayūmars, the first human being in the Zoroastrian mythology, and continues through Firiydūn, the king of the Pīšdādī era, ${ }^{103}$ Kay Huusrau, and great Sufi masters such as Hallāğ, Bāyazīd of Bastām and Abū 'l-Ḥasan Hyarqānī. ${ }^{104}$ Suhravardī articulated a philosophy that combined Neoplatonism, Mazdaism and Sufism to form the school of the 'Hikmat ul-išrāq' - Philosophy of Illumination.

The fundamental concepts of Plotinus's philosophy - emanation, the individual soul's pursuit of reunion with the One, Plato's unity of the Good, the Just and the Beautiful - influenced all of these philosophers, Sufi and non-Sufi alike.

\section{I.1.3.5 Historical Controversies Concerning hikmat and Ḥāfiẓ’s Position in the Divan}

To grasp the significance of Hāfiz’s position regarding hikmat and hakīm in the Divan, we must consider the historical backdrop against which his work was produced. Firdausī (940-1019/1025 CE), the author of Šăhnāma, ${ }^{105}$ describes Aristotle as a hakim when Aristotle mourns over the coffin of Alexander, his former student. ${ }^{106}$ Aristotle voices Firdausī's own ethical views - namely, the view

101 Seyyed Hossein Nasr, 'Shahāb al-Din Suhrawardi Maqtūl', in A History of Muslim Philosophy, ed. M. M. Sharif (Wiesbaden: Harrassowitz, 1963), p. 376.

102 See p. 36 above.

103 Behramgore Tehmuras Anklesaria, 'Zand-ākāsih: Iranian or greater Bundahišn / transliteration and translation in Engl. by Behramgore Tehmuras Anklesaria,' (Bombay 1956), Chapter: I, a, 12. \& 13. pp. 25-26. The scholarship categorizes the Pī̌̃ādī kings as mythological and the Kings of the Kayānī era as historical. It should also be mentioned that Zoroastrian believers consider the Pīšdādī kings to be also historical. In Zoroastrian texts, extraordinary attributes have been assigned to Kayānī Kings such as Kay Huusrau.

104 Nasr, 'Shahāb al-Din Suhrawardi Maqtūl', pp. 376-377.

105 Also known as The Book of Kings, this book of Persian history told in verse traverses three eras - mythological, prehistoric and pre-Islamic history of Persia up to the invasion of Persia by the second Caliph 'Umar ibn Huațāa.

106 Abu'l-Qasem Ferdowsi, The Shahnameh (The Book of Kings), ed. Djalal Khaleghi-Motlagh and Mahmoud Omidsalar, 11 vols., Persian Text Series (New York: Bibliotheca Persica, 1384/ 2005), p. 125. 
that pursuing dominance and power is unwise, given the transience of the world. In the eleventh century, following the historical confrontation between orthodox Islam and the rationalism of the Mu'tazilids, the religious orthodoxy tried to purge Islamic thinking from non-Islamic influences; Greek philosophy was disparaged as a foreign element. ${ }^{107}$ The Zāhirids, the school of theology that opposed the Mu'tazilids, held that the Qur'ān and the hadit (sayings of the prophet) are the only sources of knowledge. They viewed the Qur'ān and the hadit as native to Islam; hikmat and philosophy, on the other hand, were seen as foreign elements and thus non-Islamic. These views were reflected in the literary representation of hikmat and philosophy in the centuries that followed. In one of his qașā'id (odes), ${ }^{108}$ for instance, the first great Sufi-poet, Sanā'ì (d. $1131 \mathrm{CE}),{ }^{109}$ writes the following:

Till when, out of negligence in prayer you bad tempered hakim,

Will have the beliefs of the Greeks like the lowly?

Abandoning the truthfulness of Būbakr, ${ }^{110}$ and adeptness of Haydar ${ }^{111}$;

Then falling for Pharaoh and Hāmān! ${ }^{112}$

Reason is not reading philosophy in hope for accomplishment.

What is reason? To have a Qur'ān willing and Qur'ān reading soul. ${ }^{113}$

107 See in: Muhammad Iqbal, The Development of Metaphysics in Persia: A Contribution to the History of Muslim Philosophy (Lahore: Sang-e-Meel publications, 2004), p. 53

108 Qașa $\bar{a}^{\prime} i d$ is the plural of qașida, a verse form consisting of 15 to 70 couplets in which the first verse of the first couplet rhymes with the second verse of all the couplets of the poem.

109 The earliest of the three prominent Sufi-poet's, followed by 'Atțār (ca. 1142-1220 CE) and Rūmī (1207-1273 CE). See in: E. G. Browne, A Literary History of Persia, IV vols. (Cambridge: The University Press, 1951), vol. 2: p. 317.

Among these poets Rūmī's works differentiate between philosophy as true pursuit of knowledge and purposeless fallacies, which he believed some practiced in the name of philosophy. Rūmī expresses his utter respect for Plato and Galenus, while distancing himself from partaking in endless abstract discussions. Manūčehr Mortażavī, Maktab-e Hāafiz: Moqaddame bar ḥāfižšenāsī (Tehran: Ibn Sīnā, 1344/1965), Introduction, p. 69.

110 The first Caliph after Muhammad, famous for his honesty - hence his epithet șiddĩ $q$ (truthful).

111 Ḥaydar (lion) is the epithet of 'Alī ibn Abì Țālib, cousin of the prophet Mohammed and the fourth Caliph after the prophet; he is also the first Imām according to the Shia Muslims.

112 Pharaoh's vizier according to Qur'ān (28: 8)

113 Abū 'l-Mağd Mağdūd ibn Ādam Sanā'ī, Dīvān, ed. Modarres Rażavī, 3rd ed. (Tehran: Ketābhāne-ye Sanā'ī, 1362/1983), pp. 460-461 (my translation).

Tākiy az kāhil-namāzì iy ḥakīm-i zišt ḩū / Hamču dūnān i'tiqād-i ahl-i Yūnān dāštan

Ṣidq-i Būbakrī-yu hizq-i Ḥaydarī kardan rahā / Pas dil andar zumra-yi Fir'aun u Hāmān dāštan

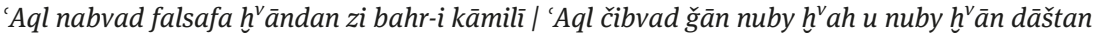


This rejection of hikmat and philosophy as foreign elements corrupting Islamic orthodoxy can be seen in Sanā'ì's direct mention of the Greek philosophical roots of hikmat. Sanā'ì names Greek philosophy alongside a series of elements signifying the otherness of the subject as Pharaoh and Hāmān. 'Atțār of the twelfth and the thirteenth centuries advanced the same view of hikmat and philosophy. In his Mușibatnāma, he writes:

Become the man of religion and confidant of the secrets

Loathe the philosophers' fantasy

Farther from the Sharia of the prophet of Hāšimīs (the prophet Muhammad's tribe),

Other than the philosopher no one can be. ${ }^{114}$

It must be mentioned that not all attacks made by Sufi poets against philosophy and hikmat were motivated by enmity against the teachings of Greek and Alexandrian philosophers; in fact, as I discuss later, the views of Neoplatonists make up the core of Sufi theosophical teachings regarding emanation. In many cases, Sufi opposition to philosophy was directed against radical rationalistic thinkers who held human reason to be sufficient to understand nature, metaphysics and even the essence of the divine. Since Sufis thought that intuition was the only way to understand the divine, they rejected the role ascribed to reason by rationalist philosophers. ${ }^{115}$ Furthermore, despite the hostility of early Sufipoets against hikmat and philosophy, some of the most important philosophers of the Islamic Peripatetic and Neoplatonic traditions considered Sufism to be a part of philosophy. Moreover, the growing trend on the part of Sufis and Sufi philosophers toward speculation and discursive representation obscured the boundaries that separated Sufism, theology, philosophy, and metaphysics.

Throughout the Divan, Hāfiz never claims to be a polymath (hakìm) on par with Ibn Sīnā, $\mathrm{H}^{\mathrm{v}} \bar{a}$ ğa Nașīr ud-Dīn Ṭūsī and Āmulī. Yet the presence of different aspects of hikmat in the Divan proves that the poet was a seeker of such knowledge. The following couplet gestures toward the poet's view of hikmat and, more importantly, of the relationship between philosophy and life: 'Hāfiẓ! From

114 Farīd ud-Dīn 'Aț̣ār, Muṣībatnāma, ed. 'Abd ul-wahhāb Nūrānī Wiṣāl (Tehran: Zawwār, 1338/1959), p. 54 (my translation).

Mard-i dīn šau, mahram-i asrār gard / Az hayāl-i falsafi bīzār gard / Nīst az šar'i nabī-yi Hāšimī / Dūrtar az falsafi ìak ādamī

115 Compare to: Nağm ud-Dīn Rāzī, Risāla-yi 'išq va 'aql (Mi'yār ul-șidq fì miṣdāq ul-'išq), ed. Taqī Tafaḍdulī (Tehran: Bongāh-e Tarğome va Našr-e Ketāb, 1345/1966), pp. 45-48. Nağm udDīn Rāzī is knowledgeable about the views of the Peripatetic Philosophers - see p. 69. However, his true debt to Alexandrian and Platonic views concerns his explanations of emanation of the divine and the hierarchic levels of benefiting from divine emanation, which is constantly present in his interpretative Qur'ān citations. See for instance p. 56; 58. 
the fountain of Philosophy, bring to hand a cup (of wisdom) | It may be that from the heart's tablet, the picture of ignorance goeth. ${ }^{116}$ In this couplet, the poet clearly acknowledges his respect for hikmat as a remedy for ignorance. Translated by Clarke as 'philosophy' and by Wohlleben and Hammer-Purgstall as 'Weisheit', ${ }^{117}$ hikmat refers to that aspect of the knowledge that overcomes ignorance and extends into life itself. In this respect, hikmat and Sufi teachings overlap.

Ignoring the wide range of meaning and practical orientation of hikmat, Clarke incorrectly translated hakīm - a person who is accomplished in hikmat as 'physician' in the following couplet. In the following poem, we find expressed the Platonic view regarding the equivalence of the Truth, the Right and the Good (șavāb and hayr). Here are Wohlleben's and Clarke’s translations:

Der Rat des Weisen ist genau das Richtige und schlechthin Gute; glücklich, wer ihn hört und akzeptiert. ${ }^{118}$

The essence of good and essentially good, is the physician's counsel:

Happy that one's fortune, who, with the ear of resignation, -heard $^{119}$

The poet views hikmat (at least in its practical aspect) as a source of clarity - a spring, as he describes it in the first quote above, from which to quench the thirst for knowledge and clear away the ignorance that clouds the faculty of judgment. ${ }^{120}$

Yet, as the following verses show, hikmat does not quench the poet's thirst entirely.

116 Translation from: Clarke, 244, 7, p. 440. The Persian couplet is the following: Hāfiz $a z$ čišma-yi hịkmat ba kaf āvar ǧāmī / Bū ki az lauh-i dilat naqšsi ǧihālat biravad. In: Qazvīnī \& Ġanī, 222, 7.

117 'O Hafis, aus der Quelle der Weisheit schöpfe mit der Hand ein | Wässerchen, | Kann sein daß von der Tafel deines Herzens das Bild des | (Gott-) Nichtwissens schwindet.' In: Wohlleben, 217, 7, p. 300. Also see: Hammer-Purgstall, vol. 1: CXXX, p. 401.

118 Wohlleben, 238, 11, pp. 323.

119 Clarke, 215, 11, p. 397. The original Persian couplet is the following:

Pand-i ḥakīm maḥż-i șavāb ast u 'ayn-i ḩayr / Farḩunda ānkasī ki ba sam'-i rażā šinīd. In: Qazvīnī \& Ġanī, 243, 11.

It is important to note that what Clarke translates as 'resignation,' the Arabic word raża, literally means 'contentment' and 'satisfaction.' If we insist on reading it in Sufi context then it would mean inner and spiritual contentment. It is does not, however, denote surrender or resignation (taslīm) or predestination ( $\check{g} a b r$ ). I should clarify that in the whole Divan there is not one instance of usage of the term ğabr as a doctrine. For submission (taslim) in the Divan see: Ibid, 59, 6, p. 146; Ibid, 169, 8, p. 324.

120 For another instance see in: Clarke, 524, 13, p. 858. 
Brave tales of singers and wine relate, The key to the Hidden 'twere vain to seek; No wisdom of ours has unlocked that gate, And locked to our wisdom it shall be. ${ }^{121}$

It is in verses such as the above that we grasp that in the Divan hikmat is subject to problematization. In other words, hikmat itself has its limits. In the couplet that follows, the poet addresses hikmat, represented by Plato. 'Save Plato, jarsitter with wine, | To us, the mystery of philosophy, who uttereth -again?'122 The philosopher who chose his house to be a vat (pithos) was Diogenes of Sinope of the fourth century BC. By alluding to this attribute of Diogenes and specifying that the jar in question is jar of wine, the poet seamlessly embeds Plato, who represents hikmat, into Haăfizian bacchanalian ġazal and the poet's quest for knowledge. This is evident in the poet's mention of wine and Plato together in a single line. By suggesting that Plato's house is a jar of wine, Hāfiz implies that Plato is the wine itself, and vice versa, thereby elevating Plato to the sole source of acquisition of knowledge (hikmat) for Ḥāfiz. Moreover, by linking wine and Plato, Hâafiz also shows that the reception of Platonic philosophy is interwoven with Sufi wine metaphors - one example of the inner-connection between hikmat and Sufi views in the Divan.

\section{I.1.4 Neoplatonic Views as the Starting Point for the Study of the Relation Between Body and Soul in Goethe's Faust and the Divan of Ḥăfiz}

The most reliable sources on Haaffiz's views regarding the body, the soul and the pursuit of truth are the Divan itself as well as writings of Hiăfiz's contemporaries. As we saw earlier, Āmulī viewed proficiency in multiple branches of knowledge as a prerequisite for all poets; Ḥāfiz would never have achieved his rank as a poet without the wide range of knowledge he possessed and to which the Divan testifies. We know from the Divan itself and from Gulandām, who assembled its poems, that Ḥăfiz had been a lecturer of theological texts and Qur'ān interpretations. In particular, he held lectures on Kaššăf, a comprehensive

121 Ḥāfiz, The Hafez Poems of Gertrude Bell, 5, p. 91. Transcription of the original Persian couplet:

Hadīs az muțrib u maī gū u rāz-i dahr kamtar ğū / Ki kas nagšùd u nagšāyad ba ḥikmat īn mu'ammā rā. In: Hูānlarī 3, 5.

122 Clarke, 306, 3, p. 530. See also in Wohlleben, 256, 5, p. 345. The Persian couplet: Ğuz Falāțūn-i ḩum-nišìn-i šarāb / Sirri hikmat ba mā ki gūyad bāz 
commentary on the Qur'ān written in the twelfth century by the theologian (ahl-i kalām) Zamahšarī, who belonged to the school of Mu'tazilids, which was deeply rooted in the rational tradition that flourished as Greek philosophy was becoming accessible through translation to Islamic world. ${ }^{123}$ As Dādbeh asserts, lecturing on Kaššâf requires knowledge of philosophy and kalām. Haāfiẓ's personal acquaintance with the founder of the philosophical school of Shiraz, 'Adud ud-Dīn İğì, and his knowledge of his work Mawāqif (The Stations) further testifies to the poet's knowledge of philosophy. ${ }^{124}$

The term hikmat and most of its branches are present in Haăfiz’s Divan. As I showed above, Hāafiz follows Āmulī's understanding of the term as philosophy in the broadest sense. Furthermore, as I showed and as I will further demonstrate throughout this study, knowledge of the truth, self-knowledge and selfdevelopment were pursued through hikmat and Sufism alike, both of which were influenced by Neoplatonism. ${ }^{125}$ Since, during Hāfiz’s time, questions concerning the pursuit of knowledge and the relation between body and soul were viewed through a Neoplatonic lens, answers to these questions advanced in the Divan must likewise be understood in light of Neoplatonic views.

As far as Goethe is concerned, we benefit from textual documentation of Goethe's study of Platonic and Neoplatonic texts. This documentation allows us to more easily approach Faust as an instance of the problematization of Neoplatonic views in the context of the relation between the body and the soul in the pursuit of knowledge.

The sixth book of the second part of Dichtung und Wahrheit provides useful information regarding Goethe's familiarity with Platonism and Neoplatonism. ${ }^{126}$ Here, Goethe notes that, as a young man, he considered that 'eine abgesonderte Philosophie sei nicht nötig, indem sie schon in der Religion und Poesie vollkommen enthalten sei. ${ }^{, 27}$ He read Johann Jakob Brucker's history of philosophy with this view of philosophy in mind. ${ }^{128}$ Regarding the earliest philosophers, Goethe writes: 'An den ältesten Männern und Schulen gefiel mir am besten, daß Poesie,

123 See pp. 32ff above.

124 Aṣgàar Dādbeh, 'Hāfiẓ’, in Dāyerat al-ma'āref-e bozorg-e eslāmī (Tehran: Markaz-e Dāyerat al-Ma'āref-e Bozorg-e Eslāmī, 1367/1988), pp. 604-605. On Īğī and Ḥāfiz see pp. 182-183 below.

125 See my brief note on the process of translation of Greek philosophy in the Islamic world and the influence of Neoplatonic views on philosophers such as Ibn Sīnā and Sufiphilosophers Suhravardī in §I.1.3.4 ('Neoplatonism in the Cultural Horizon of Ḥāfiż’).

126 FA I, 14: pp. $242 \mathrm{ff}$.

127 FA I, 14: p. 243.

128 Ibid. 
Religion und Philosophie ganz in Eins zusammenfielen'. ${ }^{129}$ Koch clarifies that Neoplatonic thinkers caught young Goethe's interest during the early stage of his studies of philosophy. ${ }^{130}$ Furthermore, Koch explains that Goethe studied the texts in Latin and that one of his sources may have been Marsilio Ficino's (1433-1499 CE) translation of the Enneads of $1486 .{ }^{131}$ In his Ephemerides, Goethe responds to a passage in Bibliographia antiquaria by Johann Albrecht Fabricius in which Fabricius condemns Spinoza's cosmology and that of Zeno, Aristotle and Plotinus ${ }^{132}$; the author then expresses his support for the position that views God and Nature as separate. Goethe critiques these passages of Bibliographia through an ontological perspective; he expresses his strong disagreement with the separation of God and Nature, asserting that 'the whole' is in the state of unity based on the one true being that is God, which is the ontological ground of the multiplicity. Furthermore, he clarifies that this view has its roots in antiquity and goes back to Plotinus. ${ }^{133}$

The Ephemerides also proves that Goethe studied Moses Mendelssohn's Phädon, oder über die Unsterblichkeit der Seele in the period between September, 1768 and March, 1770. He read this text in comparison with Plato's Phaedo and attempted to identify differences between them. ${ }^{134}$ As the title indicates, this work of Mendelssohn's focuses on providing philosophical arguments for the immortality of the soul. The line of argument in Plato's Phaedo and Mendelssohn's modifying translation of it, as Goethe also notes, has the ontological and epistemological elements as basic components contributing to their philosophical system. These spheres then determine the ethical aspect of the dialogue.

Goethe saw in Phädon the interwoven threads of multiple critiques of the method of the acquisition of knowledge - i.e. the epistemological, ethical and ontological aspects of the work. Goethe's first note highlights the ethical aspect

129 Ibid.

130 Franz Koch, Goethe und Plotin (Leipzig: Verlagsbuchhandlung J. J. Weber, 1925), pp. 19-20. Koch casting light on this fact, cites from the following source: J. W. Goethe, Goethes Werke: Herausgegeben im Auftrage der Großherzogin Sophie von Sachsen (Weimar: Hermann Böhlau, 1887-1919). I, 27, Aus Meinem Leben. Dichtung und Wahrheit, zweiter Teil p. 382.

131 Koch, Goethe und Plotin, pp. 22-24.

132 Martin Bollacher, Der junge Goethe und Spinoza: Studie zur Geschichte des Spinozismus in der Epoche des Sturm und Drangs (Tübingen: Max Niemeyer Verlag, 1969), pp. 17-19.

133 J. W. Goethe, Der Junge Goethe: Neu Bearbeitete Ausgabe in Fünf Bänden, ed. Hanna Fischer - Lamberg, 5 vols. (Berlin: Walter De Gruyter \& Co, 1963), p. 431. Compare to: Bollacher, Der junge Goethe und Spinoza: Studie zur Geschichte des Spinozismus in der Epoche des Sturm und Drangs, p. 18.

134 Goethe, Der Junge Goethe, pp. 437-439. 
of the dialogue: 'Ein Weiser stirbt gerne."135 The next note in the Ephemerids that is of importance for this study concerns the ontological realm. Mendelssohn, like Plato, believed that there existed a gap between the states of being and non-being and that the realm of natural perpetual change cannot escape or step outside of this gap. In other words, in the realm of nature, as Mendelssohn and Plato understand it, there is no coming to be and ceasing to be in an ontological sense. Rather, there is only perpetual change, as the following passage in Phädon makes clear:

So lassen sich auch, im Ganzen betrachtet, die Tage der Woche nicht unterscheiden; denn das Stetige und Aneinanderhängende läßt sich nur in der Einbildung, und nach den Vorspiegelungen der Sinne, in bestimmte und abgesonderte Theile zertrennen; der Verstand aber siehet gar wohl, daß man da nicht stehen bleiben muß, wo keine wirkliche Abtheilung ist. ${ }^{136}$

It is in this context that Goethe quotes the following passage from Mendelssohn's Phädon: 'Zwischen seyn und nicht seyn ist eine entsetzliche Kluft, die von der almählig wirkenden Natur der Dinge nicht übersprungen werden kann. ${ }^{137}$ According to this line of argument, the influence of the transcendent realm on the realm of nature and perpetual change can be explained through an ontological perspective. After this ontological remark, Mendelssohn describes the soul's journey toward knowledge and wisdom. It is only in the radical independence of the soul from the body that the soul can be recognized as eternal. This view, as Goethe notes, extends to an epistemology of independence from the body, according to which philosophy is the practice of abstraction of the body from the soul: 'Kann die Seele ohne Sinne empfinden. Sie wird die erhabne, heilige, geistische Gefühle von Schönheit, Ordnung und also von Gott haben. ${ }^{138}$ In addition, Goethe's letter to Herder from 1772 speaks to Goethe's study of Greek philosophy and literature, specifically Plato and Xenophanes. ${ }^{139}$ Werner Keller points out that Goethe's studies of Plotinus took

135 Ibid., p. 437.

136 Moses Mendelssohn, 'Phädon oder über die Unsterblichkeit der Seele', in Gesammelte Schriften. Jubiläumsausgabe Moses Mendelssohn (Stuttgart \& Bad Cannstatt: 1972), pp. 68-69. Compare to: Der Junge Goethe, p. 437.

137 Der Junge Goethe, p. 438. Also in: Mendelssohn, 'Phädon oder über die Unsterblichkeit der Seele', p. 70.

138 Der Junge Goethe, p. 438. See also in ---, 'Phädon oder über die Unsterblichkeit der Seele', pp. 53-54. (Goethe must have taken this note from Cebes's mention of Philolaus's view within Socrates's arguments.)

139 FA II, 1: pp. 255-258 especially p. 256. 
an important turn in the summer of 1805, when Goethe spent his fifty-sixth birthday in Lauchstädt. ${ }^{140}$ During this short period of seclusion, he dedicated some time to reading Plotinus's Enneads. During this time, Goethe was in frequent correspondence with Friedrich August Wolf, a philologist friend known for his expertise in Greek texts. Goethe's letter on August 30, 1805 to F. A. Wolf reveals that, during this time, Goethe tried to study the Greek texts. ${ }^{141}$ The most celebrated fruit of these studies are the four verses cited below. Keller dedicated an article to these verses in which he tried to read them in connection with Plotinus's views regarding the emanation of the transcendent in the world and the unity of the knower with the known. As Keller states, the chronological order of appearance of the verses is as follows: 'im Notizheft und als Widmungsblatt vom 1. September 1805, als zentrales Bekenntnis in der Einleitung “zum didaktischen Teil” der Farbenlehre (1810) und als "Zahmes Xenion" in der Ausgabe von 1827.142 In Farbenlehre, these verses appear in the context of a series of discursive arguments regarding the relation between the perceiving organ (the eye) and the light. Considering Goethe's knowledge of the philosophical origin of these verses, there is no doubt that they were influenced by Neoplatonic views that, in turn, were inspired by Empedocles (ca. 495-435 BCE). ${ }^{143}$

Wär' nicht das Auge sonnenhaft,

Wie könnten wir das Licht erblicken?

Lebt' nicht in uns des Gottes eigne Kraft,

Wie könnt' uns Göttliches entzücken? ${ }^{144}$

These verses, as Keller notes, are a loose translation of Plotinus's Ennead I. 6. 9. In Farbenlehre, Goethe credits the source of these verses: die 'Worte eines alten Mystikers, die wir in deutschen Reimen folgendermaßen ausdrücken möchten'. ${ }^{145}$

140 FA II, 6: Goethe’s letter: An Herzog Carl August 28.8.1805

141 FA II, 6: p. 27.

142 Werner Keller, 'Variationen zu: Wär' nicht das Auge sonnenhaft ... ', in Prägnanter Moment, ed. Peter-André Alt (Würzburg: Königshausen \& Neumann, 2002), pp. 439-461. Here p. 439.

143 Goethe specifically mentions the view of knowing the like by the like 'nur von Gleichem werde Gleiches erkannt', which reminds Goethe of 'der alten ionischen Schule'. FA I, 23/1: p. 24. On Empedocles and the idea of likeness in cognition and perception in a critical context of Aristotle's and Theophrastus's introductions and interpretations of Empedocles's view, see the following article: Rachana Kamtekar, 'Knowing by Likeness in Empedocles', Phronesis, 54, no. 3 (2009), pp. 215-238.

144 FA I, 23/1: p. 24.

145 Ibid. 
The interwoven cosmological and epistemological aspects of these verses lead to an articulation of the view of immanence in the world in Goethe's poetic adaptation of the above Ennead; they also motivate the metaphor of the sun in a context in which the sun and the human being stand in a cosmological and epistemological relation. We should also note that these words testify to an inner connection between mysticism and philosophy, a view expressed by Goethe at various points throughout his study of philosophy.

Goethe was constantly in dialogue with Platonism and Neoplatonism. Furthermore, Goethe's problematization of Neoplatonic views was inseparable from his conception of light and the sun; his exploration of questions regarding the human being's ontological and epistemological dimensions; and his interest in the way the human being lives and pursues knowledge. This context is suitable for exploring Faust within the outlines of the problematization of the pursuit of knowledge and its reflection on the body and soul relationship.

In this chapter, I have demonstrated the relevance of Platonic and Neoplatonic views to understanding Hafiz's Divan and Goethe's Faust. We are now in a position to understand the intellectual and historical adaptations that these basic views undergo in the respective cultural spaces reflected in our two texts.

\section{I.1.4.1 Becoming Sun-like or Being Sun-like}

'Were not the eye sun-like, how could we behold the light?'146 This poem is Goethe's modification and translation of a sentence in the Ennead I. 6. 9. ${ }^{147}$ But

146 FA I, 23/1: p. 24 (my translation). 'Wär' nicht das Auge sonnenhaft, | Wie könnten wir das Licht erblicken?'

147 On likeness of the eye and the sun, as well as the inner relation between the eye and the sun in the Republic, we read the following:

Neither sight nor the organ in which it resides, which we call the eye, is the sun?

No.

Yet of all the organs of sense the eye is the most like the sun?

By far the most like.

And the power which the eye possesses is a sort of effluence which is dispensed from the sun?

Exactly.

Then the sun is not sight, but the author of sight who is recognized by sight?

True, he said.

In: Plato, 'Republic', in The Dialogues of Plato Translated into English with Analysis and Introductions. Translated by B. Jowett (Oxford: Clarendon Press; reprint, Reprinted lithographically at the University Press, Oxford from corrected sheets of the fourth edition 1964, 1968), pp. 370-371. Book VI. 507 d-508 c. 
what is it that Goethe modifies here? The answer to this question shows us where, according to Goethe, the Neoplatonic view needed to be corrected.

The Ennead I. 6. 9 expounds on a process of gaining the ability to see with an eye other than the sensory one. This is apparent in the last sentence of the Ennead I. 6. 8: 'Shut your eyes, and change to and wake another way of seeing, which everyone has but few use. ${ }^{148}$ Plotinus is referring to a kind of sight that can be awakened - one that is not, like sensory perception, already active. Opening this inner eye requires going through a process of purification: 'But if anyone comes to the sight blear-eyed with wickedness, and unpurified, or weak and by his cowardice unable to look at what is very bright, he sees nothing, even if someone shows him what is there and possible to see. ${ }^{149}$ The question in Plotinus's Ennead I. 6.9 concerns becoming and not being sun-like: 'No eye ever saw the sun without becoming sun-like, nor can a soul see beauty without becoming beautiful. ${ }^{150}$ The process that one has to undergo to open the inner eye, according to Plotinus, concerns only the soul. Furthermore, it is a process of ascent: 'First the soul will come in its ascent to intellect and there will know the Forms, all beautiful'. ${ }^{151}$ Unlike in the Ennead I. 6. 9, however, Goethe views the inner eye as already active. He describes it as an ontological characteristic of the human being. The eye and the sun are already similar, Goethe thought. Furthermore, Plotinus's process of purification or ascent is absent from Goethe's version of the theory. Goethe's critical interpretation of the above Ennead problematizes one of the most cardinal aspects of Neoplatonic metaphysics - namely, the transcendent nature of the truth and the ascending method of pursuit of the truth. In Goethe's poem, the sun stands in an immediate relation to 'Gottes eigne Kraft'. It is an active principle in human beings that does not need to be 'awoken'.

148 Plotinus, Plotinus in seven volumes, trans. A. Armstrong, Henry, P. \& Schwyzer, 7 vols. (Cambridge, Mass., London: Harvard University Press W. Heinemann, 1966), I. 6. 8, vol. 1: p. 259. [Henceforth citations from the Enneads are from this translation.]

149 Ibid. I. 6. 9, p. 261.

150 Ibid., (my emphasis).

151 Ibid. Compare to the same sentence modified in Goethe's poem in Harder's German translation of the Ennead I. 6. 9: 'Man muß nämlich das Sehende dem Gesehenen verwandt und ähnlich machen, wenn man sich auf die Schau richtet; kein Auge könnte je die Sonne sehen, wäre es nicht sonnenhaft; so sieht auch keine Seele das Schöne, welche nicht schön geworden ist.'

In: Plotin, Plotins Schriften in Zwölf Bände Neubearbeitung mit griechischem Lesetext und Anmerkungen, trans. Richard Harder, 12 vols. (Hamburg: Felix Meiner Verlag, 1956), vol. 1: p. 25. 


\section{I.1.4.2 A Brief Note on the Presence of the Sun and Its Light in Plotinus's Theory of Emanation}

The Neoplatonic theory of emanation claims that the cosmos emanates from a simple, unchanging and incorporeal principle named the One. As the highest principle in Plotinus's system, the One inherits the qualities that Plato, Plotinus's predecessor, thought the highest principle must have: the One is the Good, the True, the Beautiful, the Real and the Just all at once. Whenever any of these aspects of the One is addressed, all the others are immediately and necessarily implied. The emanation itself can be described, in short, as a process in which the One bestows existence upon the multiplicity of the phenomena. Yet it is of utmost importance to note that, by definition, the One is immutable. Therefore, the two related concepts of time and movement are irrelevant to the One and its emanation; the stages of the emanation occur in an eternal continuum. ${ }^{152}$

Emanation, as Plotinus understands it, goes through the following stages: Intellect emanates from the One; the Soul of the World emanates from Intellect; and, finally, the Soul of the World imparts the intelligible, never-changing forms to heavenly bodies. The body appears for the first time at the level of heavenly bodies; prior to this stage, emanation is conceived to be a purely spiritual process. By Plotinus's definition, the body is the meeting place of the spiritual and the material. ${ }^{153}$ The aversion of Plotinus's system toward matter becomes apparent from the fact that heavenly bodies are held to be made of ether and are untouched by change and decay. ${ }^{154}$

Bearing in mind these qualities of the One, we may now address the place of the sun in Plotinus's system. Plotinus argues that the One must emanate the universe without itself being moved and changed. In the Ennead V. I. 6 (On the Three Primary Hypostases), Plotinus reasons that, if the One were moved, then anything that came from it would be two steps removed (rather than one) from the origin of the movement - yet the origin of moment, as per definition, is the One. How can something create movement without itself being moved? Here is

152 For the timelessness of the emanation process see: Ennead V. 1. 6 and in: Christia Mercer, 'Platonism in early Modern Natural Philosophy', in Neoplatonism and the Philosophy of Nature, ed. James Wilberding and Christoph Horn (Oxford: Oxford Univ. Press, 2012), pp. 103-126. Here p. 112

153 Ennead III. 4. 1. Thus, the intelligible has no other origin than the intellect, which in turn has no origin and existence other than that of the One. In short, there are no qualities or quantities which have any origin other than the One, via Intellect and the World Soul. Therefore, the intelligible is the continuum of the One in accord with the capability of the body.

154 On the hierarchic levels of the emanation see: Ennead II. 3. 17 and V. 1. 6. 
where Plotinus appeals to the metaphor of the sun. Its rays of light represent a form of begetting that (a) does not require any movement from its originating cause and (b) illustrates emanation as the necessary essence of the One: 'It must be a radiation from it while it remains unchanged, like the bright light of the sun which, so to speak, runs round it, springing from it continually while it remains unchanged. ${ }^{155}$ The sun represents the One and the rays of light represent the Intellect, the first emanation. In other words, the sun stands for the necessity of emanation that is presupposed by the essence of the One. Thus, the One emanates freely, yet at the same time necessarily and inexhaustibly, and it remains unchanged in the process. ${ }^{156}$

These are the cosmological principles that Plotinus aspires to illustrate via the sun metaphor. As I pointed out above, one of the clearest instances of the cosmological implementation of the analogy of the sun is the Ennead V. 1. 6. ${ }^{157}$ Though not as illustrative as the metaphor of the sun and its rays, Plotinus also saw the transmission of scent as a metaphor for emanation theory. Scent as a metaphor for Intellect and perfume as a metaphor for the One can be seen, for instance, in the Ennead V. 1. 2. These metaphors will also play a role in the analysis of our two texts.

Each stage of the emanation, Plotinus thought, is in love with the stage above it. This love is explained as the love of the child for its parents; the lower stage directs its quest toward the Beautiful and the Good in the stage above. This view is rooted in Plato's Symposium and the teachings of Diotima, who defined love as poverty and the recognition of need. 'Every thing longs for its parent and loves it, especially when parent and offspring are alone; but when the parent is the highest good, the offspring is necessarily with him and separate from him only in otherness. ${ }^{, 158}$ Yet Plotinus modifies this view and extends it to the One itself. Armstrong clarifies that, according to Plotinus, the One is not only 'self-

155 Ennead V. 1. 6.

156 Arthur Hilary Armstrong, The Architecture of the Intelligible Universe in the Philosophy of Plotinus: an Analytical and Historical Study, Cambridge classical studies (Amsterdam: Hakkert, 1967), p. 51.

157 See in Republic the sun juxtaposed to the source of the forms, expressed by the following simile:

'You would say, would you not that the sun is not only the author of visible in all visible things, but of generation and nourishment and growth, though he himself is not generated?

Certainly.

In like manner you must say that the good not only infuses the power of being known into all things known, but also bestows upon them their being and existence, and yet the good is not existence, but lies far beyond it in dignity and power.' Plato, 'Republic', p. 372. Book VI. 509 b.

158 Ennead V. 1. 6. 
sufficient' and 'self-directed'. It also has a unique characteristic: 'the One does not only think itself, it wills and loves itself. ${ }^{159}$ Plotinus explains the process of reunion in terms of the One's self-willing and self-loving, and he claims that the human soul contains a spark of the One itself; I will explore this view in greater depth later, when I turn to the analysis of the body and soul relation in Faust.

\title{
I.2 The Sun, Heavenly Bodies and the Call for Ascent in Faust
}

The Prolog im Himmel commences with the sun. Following Pythagorean theory, Raphael's ode celebrates the rotation of the sun as the source of a tune that the angels perceive and enjoy.

\author{
Die Sonne tönt nach alter Weise \\ In Brudersphären Wettgesang, \\ Und ihre vorgeschrieb'ne Reise \\ Vollendet sie mit Donnergang. \\ Ihr Anblick gibt den Engeln Stärke, \\ Wenn keiner sie ergründen mag; \\ Die unbegreiflich hohen Werke \\ Sind herrlich wie am ersten Tag. ${ }^{160}$
}

The sight of the sun gives the angels strength and nourishment. It reminds us of the Stoic conception of the sun as the source of energy and nourishment in the cosmos - a source of 'undiminished giving. ${ }^{, 161}$ The archangels' inability (by self-admission) to comprehend the sun recalls the Platonic and Neoplatonic metaphor of the sun as the source of emanation of all that is intelligible and which stands beyond the Intellect. The philosophical representation of the sun in the Prolog im Himmel highlights the significance of the sun to the drama as a whole.

In his first monologue, Faust characterizes the object of the knowledge he wishes to attain in several ways. It is the 'indwelling entity' that holds the world together; the seed from which the world springs; and the force that influences the world:

159 Armstrong, The Architecture of the Intelligible Universe in the Philosophy of Plotinus: an Analytical and Historical Study, p. 12.

160 V. 243-250.

161 Armstrong, The Architecture of the Intelligible Universe in the Philosophy of Plotinus: an Analytical and Historical Study, p. 53. 
Daß ich erkenne was die Welt

Im Innersten zusammenhält,

Schau' alle Wirkenskraft und Samen,

Und tu' nicht mehr in Worten kramen. ${ }^{162}$

In these verses, ${ }^{163}$ there is no mention of an upward path that might lead to a source of knowledge and being. Furthermore, there is no mention of a 'hierarchy of being' as a characteristic of the transcendent source of truth. Rather, Faust describes a triad - forces, seeds and the world - that creates a whole. This can be understood either as a modification of the Platonic emanation theory or as an articulation of Spinoza's substance/attribute/mode triad of monistic Nature. ${ }^{164}$ (Recall that these lines were written after Goethe's study of Spinoza and his speech Zum Shakespears Tag.) This controversial issue, however, is not the subject of this study. For the purposes of tracing the problematization of Platonic views in Faust, it suffices to note that Faust appears to view the acquisition of knowledge in terms of a world that is principally immanent.

\section{I.2.1 Direct Approach to the Transcendent: Pain, Escape and Fall}

In the following verses, Faust fixes his gaze on the moon and recalls many nights in which the moon and its gloomy light were his only friends:

O sähst du, voller Mondenschein,

Zum letztenmal auf meine Pein,

Den ich so manche Mitternacht

An diesem Pult herangewacht:

Dann, über Büchern und Papier,

Trübsel'ger Freund, erschienst du mir! ${ }^{165}$

Remarkably, Faust's summoning the presence of the moon coincides with an expression of pain and alarm. Yet the pain turns into a delirious ecstatic fantasy of bathing in the moon's dew - a mystical urge for direct ascent and union that is described in sensual language:

162 V. 382-385.

163 These verses were part of the drama since the Faust frühe Fassung, which, as Schöne informs us, can be traced back to the years 1776 and 1777. See in: FK, p. 81.

164 For a comprehensive account of the relation between Goethe and Herder and the speech On Shakespeare's Day of 1771 see Bollacher, Der junge Goethe und Spinoza: Studie zur Geschichte des Spinozismus in der Epoche des Sturm und Drangs, pp. 167-175 \& pp. 234-237.

165 V. 386-391. 


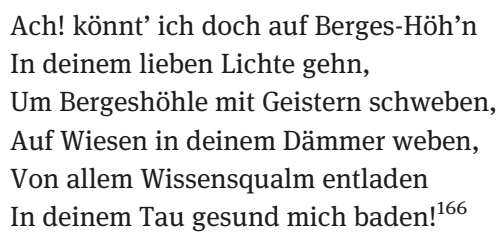

Faust's escape into his fantasy of reaching directly for the moon is followed by a fall back to reality - the 'Kerker', as Faust describes it. Verses 398-409 depict the state of Faust's life in a world that he inherited from his forefathers, practitioners of alchemy and magic. Faust had restrained himself from these activities up until this point:

\author{
Weh! steck' ich in dem Kerker noch? \\ Verfluchtes dumpfes Mauerloch, \\ Wo selbst das liebe Himmelslicht \\ Trüb' durch gemalte Scheiben bricht! ${ }^{167}$
}

This world contained within these walls is the location where Faust suffers this pain. Initially, Faust conceptualizes his pain as a call that conveys his longing for the truth, a concept that is articulated poetically via light metaphors - these metaphors are consistent with 'the ascending tradition' that we discussed earlier. The scene's gothic room is constructed in such a way that light only penetrates its stained-glass windows.

In the scene Nacht Faust expresses another wish for escape - an urge to get out immediately and flee to faraway lands: 'Flieh! Auf! Hinaus in's weite Land! ${ }^{168}$ Evidently, this urge for escape takes the form of an urge for ascent, thereby paving the way for Faust's first speculative fantasy in pursuit of ascent the path to which, according to Faust, is described in the book of Nostradamus.

\title{
1.2.1.1 Escape in Speculative Fantasy
}

Faust's inclination toward a world-view built around a principally immanent system emerges as he reads the macrocosm sign. Faust immediately integrates the microcosm into the macrocosm ('Bin ich ein Gott?') as he forms an understanding of the macrocosm. ${ }^{169}$ His senses are the first to experience the speculative vision:

166 V. 392-397.

167 V. 398-401.

168 V. 419.

169 V. 434-439. 
Ha! welche Wonne fließt in diesem Blick

Auf einmal mir durch alle meine Sinnen!

Ich fühle junges heil'ges Lebensglück

Neuglühend mir durch Nerv' und Adern rinnen ${ }^{170}$

Following the moon, which appeared at the beginning of the Nacht scene, the sun - likewise a heavenly body - now appears in Faust's reading of the macrocosm sign. The sun is represented by the metaphor of golden buckets, a metaphor that is taken from everyday life and that, therefore, brings the scene closer to its audience. Here, an emanative system is described in a manner that resembles the Platonic and Neoplatonic similes of light and scent. In accordance with the Platonic tradition, the emanation proceeds from above; rays of light emanate from heaven and resonate through existence, as though 'passing' golden buckets from one person in line to the next. However, even at this early point in the drama, we discern a clear difference between Faust's speculative vision and Platonic and Neoplatonic views - namely, there is no sign of any resistance toward the flow of this heavenly Goodness in Faust's account. In this moment of envisioned speculation, as if under the magical influence of the macrocosm sign, the above difference allows Faust's body - his 'Nerv' und Adern,' and not merely his intellect - to be influenced as well. Body and the soul both participate in the appreciation of the moment. This speculative vision includes 'Blick', 'schauen' and 'erkennen' of what 'die Welt im Innersten zusammenhält' in Faust's vision ${ }^{171}$ :

Wie alles sich zum Ganzen webt, Eins in dem andern wirkt und lebt!

Wie Himmelskräfte auf und nieder steigen

Und sich die goldnen Eimer reichen!

Mit segenduftenden Schwingen

Vom Himmel durch die Erde dringen,

Harmonisch all' das All durchklingen! $!^{172}$

The only hindrance here is on the receiving end - namely, the human's incapable 'sense' and dead 'heart':

Jetzt erst erkenn' ich was der Weise spricht:

'Die Geisterwelt ist nicht verschlossen;

Dein Sinn ist zu, dein Herz ist tot!

170 V. 430-433.

171 V. 430; 440; 442; 382-385. Also compare to: Hans Arens, Kommentar zu Goethes Faust I (Heidelberg: Carl Winter Universitätsverlag, 1982), p. 86.

172 V. 447-453. 
Auf, bade, Schüler, unverdrossen

Die ird'sche Brust im Morgenrot! ${ }^{173}$

In the words of the 'Wise One,' ascension and purification are necessary for us to make the 'earthly bosom' capable of appreciating this light. ${ }^{174}$ Yet we face a discrepancy: although the immanence of the One is homogenous and uninterrupted, its appreciation by 'Sinn' and 'Herz', as Faust says, is neither unconditional nor universal. At first glance, it may appear that there is no way to describe how the senses and the earthly bosom open to 'die Geisterwelt'; nonetheless, it is suggested that the 'Schüler' bathes the earthly bosom in the red light of dawn, thereby imagining the sensual ('Sinn') and spiritual ('Herz') experience of revolving around the sun. The rhetoric of negative and purifying ascent to transcendent truth is clearly present in the description of this bathing. These four verses are clearly different from the one written in 1805 in Lauchstädt. In verses 443-446 even in the midst of this joyous moment, the eye and the senses are depicted as 'closed' and the heart as 'dead'. This description highlights the necessity of purification. The exhortation to profound purification was also at the core of the Ennead I. 6. 9, yet Goethe's poetic reconstruction of the Ennead (in all of its variations since 1805) ignored this point.

For Faust, who zealously yearns for a sensual experience of immanent Nature, all these visions are deemed to be one magnificent spectacle - and nothing more. Bathing in the 'Morgenrot' only leads to another painful fall:

\footnotetext{
Welch Schauspiel! aber ach! ein Schauspiel nur!

Wo fass' ich dich, unendliche Natur?

Euch Brüste, wo? Ihr Quellen alles Lebens,

An denen Himmel und Erde hängt,
}

173 V. 442-446.

174 Regarding the figurative meaning of 'Brust' and 'Herz', we turn to Adelung's dictionary, which glosses 'Brust' as 'Die untern [sic] Kräfte der Seele, die man sonst auch das Herz nennet, weil dasselbe seinen Sitz in der Brusthöhle hat, besonders bey den Dichtern.' Johann Christoph Adelung, Versuch eines volständigen grammatisch-kritischen Wörterbuch der Hochdeutschen Mundart, 5 vols. (Leipzig (1774-1786)), vol. 1: p. 1105. On the figurative meanings of 'Herz' he writes: 'Am häufigsten die Seele des Menschen und deren besondere Fähigkeiten.' He also clarifies that this usage appears in Luther's translation of the Bible. See, for instance, Job 12. 3, where the word 'Herz' is used figuratively instead of 'Gehirn'. In this regard, Adelung further explains: 'Im Deutschen ist es in diesem Sinne nicht üblich, wo man es theils [sic] noch von den Gedanken des Menschen, theils aber auch, und zwar am häufigsten, von dem ganzen Empfindungs- und Begehrungsvermögen und dessen Äußerungen in besondern Fällen braucht.' ibid., vol. 2: p. 1146. 
Dahin die welke Brust sich drängt -

Ihr quellt, ihr tränkt, und schmacht' ich so vergebens? ${ }^{175}$

As we saw, Faust longs to appreciate the immanent presence of the transcendent as boundless nature; yet he does not know how to grasp nature in such a sensual unity. Faust's self-criticism doesn't do him any more good than opening yet another page of the book of Nostradamus. Now the 'Erdgeist' is in front of him: 'Du, Geist der Erde, bist mir näher' ${ }^{176}$ Faust deems this soul to be at 'a lesser level of transcendence' and therefore closer to him:

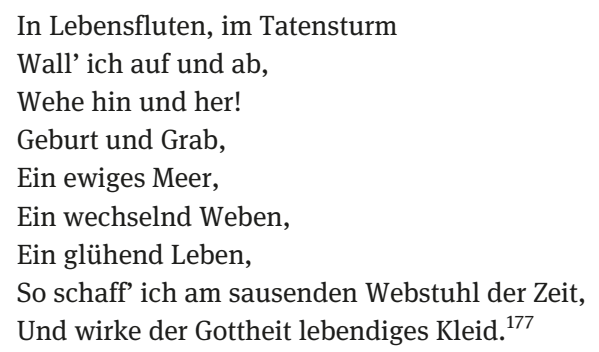

The 'Erdgeist' introduces itself as an active and organic unity that contains multiple polarities: 'auf und ab', 'hin und her', 'Geburt und Grab'. In this scene, Nature can be best understood in the context of Goethe's Zum Shakespears Tag:

[D]as was wir das bös nennen, ${ }^{178}$ ist nur die andre Seite vom Guten die so notwendig $z u$ seiner Existenz und in das Ganze gehört, als zona torrida brennen und Lapland einfrieren muß daß es einen gemäßigten Himmelsstrich gebe. ${ }^{179}$

In this part of the speech, Goethe first describes Good and Evil as two poles or sides of a unique whole. He then expands his view by stressing the necessary polar coexistence of countless binary extremes in 'das Ganze'. It must be noted that the 'Erdgeist' has the qualities attributed to the All.

175 V. 454-459 (my emphasis).

176 V. 461.

177 V. 501-509.

178 Seen in the context of the text, it becomes clear that Goethe immediately distances himself even from recognizing anything as Good and Evil. Consider the way he refers to these two poles: 'Das was wir [. . . ] nennen.'

179 Zum Shakespears Tag. In: Ästhetische Schriften 1771-1805, FA I, 18: pp. 9-12. Here p. 12 (my emphasis). 


\section{I.2.2 The Problematization of a Method}

The cosmic order of nature that Faust envisioned in his reading of the macrocosm sign appears before him as the incarnate 'Erdgeist'. Yet the immanence and the unity of the dichotomies contradict Faust's wish to be recognized as 'göttergleich'. At this stage, the discrepancy between Faust's separation from the world (as an observer) and his vision of immanence that integrates the human being into nature becomes problematic. ${ }^{180}$ This, however, cannot be understood as unnatural - Goethe's dramatic plot seems to share a characteristic that he praises in Shakespeare's works ${ }^{181}$ :

[S]eine Stücke drehen sich alle um den geheimen Punkt (den noch kein Philosoph gesehen und bestimmt hat) in dem das Eigentümliche unseres Ichs, die prätendierte Freiheit unseres Wollens mit dem notwendigen Gang des Ganzen zusammenstoßt. ${ }^{182}$

The willing subject strives for unity with the All, but knows that it is impossible to achieve: Goethe sees this conflict in Shakespeare's characters and explains it as a conflict between the pretended freedom of will in the face of the necessary flow of the whole. Being human in this paradoxical state does not diminish the dramatic construct of the work. In fact, as a philosophical principle about nature it accounts for Goethe's remark concerning Shakespeare: 'Und ich rufe, Natur, Natur! nichts so Natur als Shakespeares Menschen. ${ }^{183}$

In the scene Nacht, we observe a seeker in his loneliness with a book opened before him. He is talking to the moon, speculating and dreaming. Isolated from all that is natural, he wishes to experience an immanence in which the all and the All are in unity - or as he says, 'Harmonisch all' das All durchklingen.' ${ }^{\text {, }}{ }^{\text {In }}$ this setting, Faust forces the 'Erdgeist' to appear in his dark 'Kerker': 'Du mußt! du mußt! und kostet' es mein Leben!'185 As soon as Faust is free of Wagner's questions, he criticizes himself for having forced nature:

180 See in: Bollacher, Der junge Goethe und Spinoza: Studie zur Geschichte des Spinozismus in der Epoche des Sturm und Drangs, pp. 168-170; p. 174. Bollacher explains Goethe's views regarding the immanence and titanic views in relation with Goethe's Spinoza studies, his monistic world-views, and their relation to integration of the human into nature.

181 'Wir ehren heute das Andenken des größten Wanderers und tun uns dadurch eine Ehre an. Von Verdiensten die wir zu schätzen wissen haben wir den Keim in uns.' In: Zum Shakespears Tag. In: ‘Ästhetische Schriften 1771-1805’ FA I, 18: p. 9.

182 Ibid., p. 11 (my emphasis).

183 Ibid.

184 V. 453.

185 V. 481. See also the words of the 'Erdgeist' as it mocks Faust for being awed in its sight: v. 483-485. 
Läßt sich Natur des Schleiers nicht berauben, Und was sie deinem Geist nicht offenbaren mag,

Das zwingst du ihr nicht ab mit Hebeln und mit Schrauben. ${ }^{186}$

This aggressive method of acquisition of knowledge is treated by Goethe in his Farbenlehre. ${ }^{187}$ Goethe criticizes the stage that Newton sets up for his experiment. ${ }^{188}$ Faust's dark room, which Mephisto later describes as a 'Marterort' (v. 1835), does not seem to be any different from the 'Marterkammer' and 'die dunkle Kammer' ${ }^{\text {'18 }}$ that Schöne addresses in Goethes Farbentheologie. For instance, we read in the Zahme Xenien VI of 1827:

\footnotetext{
Freunde flieht die dunkle Kammer Wo man euch das Licht verzwickt, Und mit kümmerlichstem Jammer Sich verschrobnen Bilden bückt. Abergläubische Verehrer Gab's die Jahre her genug, In den Köpfen eurer Lehrer Laßt Gespenst und Wahn und Trug.

Wenn der Blick an heitern Tagen Sich zur Himmelsbläue lenkt, Beim Siroc der Sonnenwagen Purpurrot sich niedersenkt, Da gebt der Natur die Ehre, Froh, an Aug' und Herz gesund, Und erkennt der Farbenlehre Allgemeinen ewigen Grund. ${ }^{190}$
}

The words of the first stanza are the same as those used to describe Faust's 'Marterort'. ${ }^{191}$ And the second part of the verses above follows the first in a manner that reminds us of the words of the Wise One in the scene Nacht. Yet this poem reflects Goethe's re-interpretation of the Ennead I. 6. 9; accordingly, there

186 V. 673-675.

187 On the relevance of Goethe's criticism of scientific methods to this scene in Faust, also see Schöne's comments on these verses in FK, p. 225.

188 See poems and fragments from 1806, 1823 and 1827 that orbit around Goethe's critique of method of acquisition of knowledge and torturing of the phenomenon in: Albrecht Schöne, Goethes Farbentheologie (München: Beck, 1987), pp. 63-67.

189 Ibid., p. 64.

190 FA I, 2: pp. 677-678.

191 Compare to: Schöne, Goethes Farbentheologie, p. 64. These verses can also be found in Appendix 52 of Schöne's book. In: ibid., p. 209. 
is no purification required to acquire knowledge. It suffices to observe nature with the naked eye. In this context, Faust's self-criticism in verses 673-675 can be understood as his critique of a method of pursuit of knowledge that manufactures a vision of the All that cannot include the seeker of knowledge.

\section{I.2.3 Suicide as a Way of Transcending the Body}

After reflecting on his failed experience with the 'Erdgeist', Faust comes to a conclusion regarding his suffering: he credits it to the opposing directions toward which the soul and the body strive. ${ }^{192}$ Faust blames the corporeal realm for thwarting his efforts whenever he attempts to ascend toward the absolute.

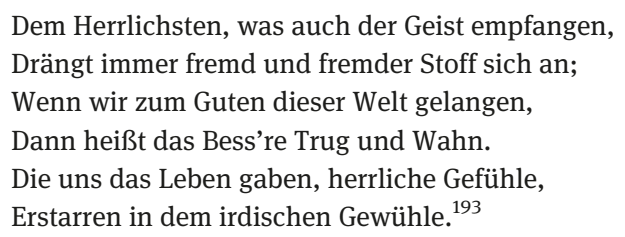

The complaints of Socrates in Phaedo come to mind. In the Ephemerides, Goethe mentions the Platonic notion of the separation of body and soul as a condition for acquiring the truth. Faust appears to share this Platonic view: 'Für den Leib sorgt der Weise nicht. Denn er ist ihm vielmehr beschwerlich. Die Seele kann sich schweer [sic] zur betrachtung [sic] der geistigen Wesen erheben., ${ }^{\text {194 }}$

The seeker of knowledge, Plato's Socrates says, should 'rid as far as he can, of eyes and ears, and so to speak, of the whole body, these being in his opinion distracting elements which when they associate with the soul hinder her from acquiring truth and knowledge'. ${ }^{195}$ The body disparages the higher aspirations of the soul as 'Trug und Wahn' and the soul, after many failures, learns to be content with the meager space of the body. 'Sorge' is introduced as the body's way of attaching itself to the soul.

Die Sorge nistet gleich im tiefen Herzen,

Dort wirkt sie geheime Schmerzen,

192 Compare to: FK, p. 224.

193 V. 634-639.

194 Der Junge Goethe, p. 437.

195 Plato, 'Phaedo', in The Dialogues of Plato Translated into English with Analysis and Introductions. Translated by B. Jowett (Oxford: Clarendon Press; reprint, Reprinted lithographically at the University Press, Oxford from corrected sheets of the fourth edition 1964, 1967), p. 416.66 a. 
Unruhig wiegt sie sich und störet Lust und Ruh;

Sie deckt sich stets mit neuen Masken zu,

Sie mag als Haus und Hof, als Weib und Kind erscheinen,

Als Feuer, Wasser, Dolch und Gift. ${ }^{196}$

In other words, the body is actively involved in leading the soul astray and obstructing its ascending quest. As we read in verses 647-651 of Faust, an active will engineers these fears and masks them with the mundane to keep the soul concerned and attached to the body. 'Du bebst vor allem was nicht trifft, | Und was du nie verlierst das mußt du stets beweinen., ${ }^{197}$

Matter is to blame for all of these misdeeds. Fire is the element used to forge iron into daggers, Faust reflects; and water is the essence of poison, a symbol of treason and deception. Socrates, too, identifies the body with seduction, want and distractions of 'Haus, und Hof' and 'Weib und Kind'. In Phaedo, we read the following:

For the body is a source of countless distractions by reason of the mere requirement of food, and is liable also to diseases which overtake and impede us in the pursuit of truth: it fills us full of loves, and lusts, and fears, and fancies of all kind [...] Whence come wars, and fightings, and factions? whence but from the body and the lusts of the body? All wars are occasioned by the love of the money, and money has to be acquired for the sake of the body and in slavish ministration to it $^{198}$

Schiller read the Faust drama against the background of the seeker of knowledge and the relationship between body and soul. ${ }^{199}$ In his doctoral dissertation, which provided a brief history of various conceptions of the body and soul relation, he addressed a commonly held view of his time - namely, that the body is a 'distraction' for the thinker because it has needs and desires. He invites the reader to understand these 'interruptions' as a call from Mother Earth that awakens the dreamer and reminds him of his attachment to the earth. These complaints are

196 V. 644-649 (my emphasis).

197 V. 650-651.

198 Plato, 'Phaedo', p. 417, 66 b \& c (my emphasis).

199 In Schiller's letter to Goethe from June 23, 1797, a time at which Goethe was concentrated on filling the great gap in Faust I, we read the following: 'Die Duplizität der menschlichen Natur und das verunglückte Bestreben das Göttliche und das Physische im Menschen zu vereinigen verliert man nicht aus den Augen, und weil die Fabel ins Grelle und Formlose geht und gehen muß, so will man nicht bei dem Gegenstand stille stehen, sondern von ihm zu Ideen geleitet werden.' In: Friedrich Schiller, Briefwechsel Schillers Briefe 1.11.1796-31.10.1798, ed. Lieselotte Blumenthal \& Benno v. Wiese, 42 vols., Schillers Werke Nationalausgabe (Weimar: Hermann Böhlaus Nachfolger, 1977), pp. 86-87. 
strikingly similar to those found in Faust and Phaedo. Schiller's words may be read as the body's answer to Faust's complaint in verses 634-651:

Der Geist, wenn er einmal in den Geheimnissen einer höhern [sic] Wollust eingeweiht worden ist, würde mit Verachtung auf die Bewegungen seines Gefährten herabsehen, und den niedrigen Bedürfnissen des physischen Lebens nicht leicht mehr opfern wollen, wenn ihn nicht das thierische [sic] Gefühl darzu [sic] zwänge. Den Mathematiker, der in den Regionen des Unendlichen schweifte, und in der Abstraktionswelt die wirkliche verträumte, jagt der Hunger aus seinem intellektuellen Schlummer empor, den Physiker, der die Mechanik des Sonnensystems zergliedert und den irrenden Planeten durchs Unermessliche begleitet, reißt ein Nadelstich zu seiner mütterlichen Erde zurück; den Philosophen, der die Natur der Gottheit entfaltet und wähnet, die Schranken der Sterblichkeit durchbrochen $\mathrm{zu}$ haben, kehrt ein kalter Nordwind, der durch seine baufällige Hütte streicht, zu sich selbst zurück, und lehrt ihn, daß er das unselige Mittelding von Vieh und Engel ist. ${ }^{200}$

The heavenly bodies and their light are associated with the wish to fly and transcend earthly boundaries. As Faust fixes his gaze on the poison, a fantasy of moonlight in the forest kindles his desire for lightness and flight. The poison promises release from failure and suffering:

Doch warum heftet sich mein Blick auf jene Stelle?

Ist jenes Fläschchen dort den Augen ein Magnet?

Warum wird mir auf einmal lieblich helle,

Als wenn im nächt'gen Wald uns Mondenglanz umweht? ${ }^{201}$

Suicide as a means of ascent to the heavenly realm is a subject of Phaedo. In fact, Goethe's notes on Phädon begins with precisely this issue: 'Ein Weiser stirbt gern. So beginnt das Gespräch. Eine kleine Abhandlung über den Selbstmord. ${ }^{202}$ In the short section to which Goethe refers in this note, both Plato and Mendelssohn advance arguments against suicide. They argue that suicide is an unacceptable way to bridge transcendent truth with life in the body, a state that both authors view as equivalent to ignorance. 'Ein Weiser, fängt er an, lernt seine ganze Lebzeit durch sterben. Der Tod setzt er voraus sey eine Trennung des Leibes und der Seele. ${ }^{203}$ These notes refer to the most controversial passage of Plato's Phaedo, represented with caution in Mendelssohn's work: 'In fact the true

200 -- - , Versuch über den Zusammenhang der thierischen Natur des Menschen mit seiner geistigen (Stuttgard 1782: Cotta [Faks.-T.].) (Ingelheim: Boehringer, 1959), pp. 9-10 (my emphasis).

201 V. 686-689.

202 Der Junge Goethe, p. 437.

203 Ibid. 
philosophers, Simmias, are always occupied in the practice of dying' ${ }^{204}$ If philosophy is the practice of separating the soul from the body, then it follows that philosophy is a lifelong practice of preparing for death. Yet there is an important distinction between advocating for suicide (Plato most certainly doesn't) and articulating a way of life that emphasizes the abstraction of the soul from the body and that outlines the ascending pursuit of truth. This manner of pursuit of truth finds its metaphorical articulation in the parable of the cave in the Republic. As Smith points out, Porphyry offers a Neoplatonic explanation of this method of life and pursuit of knowledge. Porphyry describes the spiritual death of the true seeker as one 'in which the soul may, in a positive sense, distance and thus separate itself from the distractions of the body. ${ }^{205}$ Logically intertwined with the ethic of ascent in the Platonic tradition, this epistemology is a way of life. Yet, considering Phaedo's portrayal of Socrates as welcoming of death and the fact that the dialogue has difficulty refuting arguments in favor of suicide, ${ }^{206}$ we cannot deny the strong association between the negative pursuit of truth and death.

Faust's attempts at ascension repeatedly fail. In desperation, he now resolves to leave the earthly realm behind and to flee the cycle that traps him the cycle of pain, escape into fantasy and falling back to reality. Each time he sees or thinks of heaven and heavenly bodies - made of ether, according to the Platonic and Neoplatonic philosophies -, Faust's urge burns again. Thus, Faust's only wish is for upward movement - 'Auf neuer Bahn den Äther zu durchdringen'. ${ }^{207}$ Yet unlike that of the biblical Elijah, ${ }^{208}$ Faust's ascent is horrific: 'Nach jenem Durchgang hinzustreben, | Um dessen engen Mund die ganze Hölle flammt'. ${ }^{209}$ Before he reaches for the poison, Faust thinks of the sun. He regretfully encourages himself to turn his back to the earth's precious sun in the hope of reaching the incorporeal realm of ether ${ }^{210}$ : 'Ja, kehre nur der holden

204 Plato, 'Phaedo', p. 418. 67, e. See also ibid. p. 435. 80, e.

205 Sententiae, Sent. 8 In: Andrew Smith, 'The Significance of 'Physics' in Porphyry', in Neoplatonism and the philosophy of nature, ed. J. Wilberding and C. Horn (Oxford: Oxford University Press, 2012), p. 32.

206 See in Plato, 'Phaedo', p. 412.62 b \& c. Cited on p. 85 below.

207 V. 704-705.

208 Schöne points out the biblical allusion that Goethe utilizes here as he refers to the Elijah's ascent to heaven. FK, p. 226.

209 V. 716-717.

210 It is worth mentioning that, for Plato in Republic, the sun is the most precious thing in the visible world: 'And this, you must understand, is he whom I call the child of the good, whom the good begat in his own likeness, to be in the visible world, in relation to sight and the things of sight, what the good is in the intellectual world in relation to mind and the things of mind' in: Plato, 'Republic', pp. 370-371. Book VI. 507d-508c. 
Erdensonne | Entschlossen deinen Rücken zu!'211 Once again, Faust prepares to force himself beyond his human limits: 'Vermesse dich die Pforten aufzureißen, | Vor denen jeder gern vorüber schleicht. ${ }^{212}$ Earlier in the scene Nacht, Faust resorted to force to summon the 'Erdgeist', and thereby risked his own life: 'Du mußt! du mußt! und kostet' es mein Leben!' ${ }^{213}$ Now he is willing to risk his life again: 'Zu diesem Schritt sich heiter zu entschließen | Und wär' es mit Gefahr, in's Nichts dahin zu fließen. ${ }^{214}$

Earth and heaven are juxtaposed as the ascent toward the heavens meets with heavenly songs. This unfolds in three stages: first, Faust complains about his failure to conceive of himself as immanent and God-like. His complaint highlights his feelings of rejection as he, metaphorically speaking, knocks on the doors of the immanent divine nature ${ }^{215}$ : 'Was sucht ihr, mächtig und gelind, | Ihr Himmelstöne, mich am Staube? ${ }^{, 216}$ This complaint then leads to an admission: ' $\mathrm{Zu}$ jenen Sphären wag' ich nicht zu streben, | Woher die holde Nachricht tönt'. ${ }^{217}$ Finally, Faust's skepticism is overwhelmed by emotions caused by memories of childhood: 'Und doch, an diesen Klang von Jugend auf gewöhnt, | Ruft er auch jetzt zurück mich in das Leben. ${ }^{218}$

Again, heaven and earth are mentioned together as Faust returns to earth. In the following verses, the circularity of Faust's actions is remarkable. In longing for ascent, Faust strives downwards toward what he recognizes as hell ${ }^{219}$; yet from above, heavenly songs awaken his childhood memories and return him to earth.

\footnotetext{
Erinnerung hält mich nun, mit kindlichem Gefühle,

Vom letzten, ernsten Schritt zurück.

O tönet fort ihr süßen Himmelslieder!

Die Träne quillt, die Erde hat mich wieder! $!^{220}$
}

211 V. 708-709 (my emphasis).

212 V. $710-711$.

213 V. 481.

214 V. $718-719$.

215 Faust's endeavor to grasp the limits of his individuality continues to be present in the Pact Scene: 'Ich habe mich zu hoch gebläht; | In deinen Rang gehör' ich nur. | Der große Geist hat mich verschmäht, | Vor mir verschließt sich die Natur.' (V. 1744-1747). This quest for the place of the 'Ich' will be explored further in this study.

216 V. 762-764.

217 V. 767-768.

218 V. 769-770 (my emphasis).

219 See v. 717.

220 V. 781-784. 
Though overwhelmed, Faust is able to critically evaluate his emotions: he describes them as childish feelings rooted in childhood experiences. It is no wonder therefore, that the series of curses Faust casts in the so-called Pact Scene begins with cursing these feelings (v. 1585-1589). In the poem Prometheus, there is a remarkable passage in which the sun joins with the wish for ascent and childish hopes and thereby introduces part of Goethe's poetic critique of religion:

\author{
Da ich ein Kind war, \\ Nicht wußte wo aus noch ein, \\ Kehrt' ich mein verirrtes Auge \\ Zur Sonne, als wenn drüber wär' \\ Ein Ohr zu hören meine Klage, \\ Ein Herz wie mein's, \\ Sich des Bedrängten zu erbarmen. ${ }^{221}$
}

In this instance, the sun and the wish for ascent are in direct connection. In these rebellious verses, moreover, Prometheus admits that, as a child, he too had hoped for sympathy from the heavens. The awakened Titan depicts this sentiment as childish folly.

\title{
I.2.4 Flying toward the Setting Sun
}

After his suicide attempt, Faust exits his dark cell for the first time in the drama and walks in nature. On this stroll, he experiences the outside world introspectively. Two well-known poetic monologues from this scene focus on the sun. In this section, I address the second monologue. (I explore the first monologue in the chapter Toward Life.)

Near the end of the scene Vor dem Tor (v. 1069-1099), the sight of the setting sun offers Faust respite from his grief concerning his lack of knowledge. The sight of the sun kindles in him the wish for ascent; he yearns for wings with which to fly toward the sun: 'O daß kein Flügel mich von Boden hebt, | Ihr nach und immer nach zu streben!'222 Faust dreams with his eyes open and fixed on this natural spectacle. In his fantasy, he flies toward the sun. The fantasy continues until the sun vanishes from the horizon. Suddenly, the old wound the urge to ascend - reopens. Once again employing a light metaphor, Faust articulates this tendency as the desire to drink from the eternal light of the sun

221 FA I, 1: p. 329-330 (my emphasis).

222 V. 1074-1075 (my emphasis). 
while floating between the darkness of matter and the spiritual light (night and day, and the waves and the heaven).

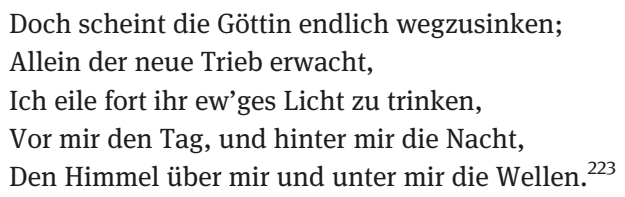

The direction of Faust's ascent here is the same as the ascent in Plato's allegory of the cave. If the macrocosm vision was a spectacle - 'ein Schauspiel nur' -, in this scene, Faust interprets his experience as a dream: 'Ein schöner Traum, in dessen sie entweicht. ${ }^{, 22}$ Since the soul's wings are like fantasy's 'kühnem Flug' (v. 640-641) and are again sabotaged by the 'körperlicher Flügel', Faust directs his complaints to the body once again. This time, the complaint commences with an expression of great loss and pain: 'Ach! zu des Geistes Flügeln wird so leicht | Kein körperlicher Flügel sich gesellen.,225

Faust turns toward justifying the longing in his soul that 'hinauf und vorwärts dringt'. ${ }^{226}$ He explains the origin of these urges in a manner suggestive of the anamnesis. There is an innate yearning, he asserts, that stirs in human beings whenever their gaze falls on phenomena that remind them of their transcendent nature. Illustrating this point, Faust provides three examples that draw attention to the heavens: the resonating song of a lark flying in the empty sky; the depths below an eagle's widely-spread wings; and finally, the image of striving back home ${ }^{227}$ :

Doch ist es jedem eingeboren,

Daß sein Gefühl hinauf und vorwärts dringt,

Wenn über uns, im blauen Raum verloren,

Ihr schmetternd Lied die Lerche singt;

Wenn über schroffen Fichtenhöhen

Der Adler ausgebreitet schwebt,

Und über Flächen, über Seen,

Der Kranich nach der Heimat strebt. 228

223 V. 1084-1088.

224 V. 1089.

225 V. 1090-1091.

226 V. 1093.

227 Compare to Plato, Phaedrus, trans. Christopher Rowe, Classical Texts (Warminster: Aris \& Phillips, 1986), p. 67. 249 d 5ff.

228 V. 1092-1099 (my emphasis). 
Faust's words connect the dots between noticing the heaven; ascending as high as possible; and then striving to return back home. In the Ennead I. 6. 8, the process of ascent culminates in reunion. This reunion is articulated as a call to fly back to 'our homeland' and 'our Father'. ${ }^{229}$ In his comments on this passage, Armstrong points out that Plotinus's description of the path of ascent refers to The Iliad 2. 140, when Agamemnon tries to convince his comrades to sail back to their homeland. This is a call for the reunion of the undescended part of our souls - as Plotinus describes it in the Ennead V. 1. 10-12 and which Inge names the 'divine nucleus ${ }^{, 230}$ - with the One. 'Our country from which we come is there, our Father is there. How shall we travel to it, where is our way to escape?'231

In the following verses, the first line of which is interrupted by an outburst of grief, the dichotomy between body and soul finds its clearest articulation:

Zwei Seelen wohnen, ach! in meiner Brust,

Die eine will sich von der andern trennen;

Die eine hält, in derber Liebeslust,

Sich an die Welt, mit klammernden Organen;

Die andere hebt gewaltsam sich vom Dust

$\mathrm{Zu}$ den Gefilden hoher Ahnen. ${ }^{232}$

Faust acknowledges the existence of two souls residing in his chest: one devoted to the material body and its needs; the other striving for ascent. More importantly, Faust also asserts that one of these two souls is determined to separate itself from the other. The verses that follow allow us to identify which of the two souls seeks to separate itself. Faust describes the modes of activity characteristic of each soul. Inclusion is the essential characteristic of the first soul: it grabs hold of - 'hält' - and clings with its 'klammernden Organen' to the world. Separation is the essential characteristic of the second soul: it wants to ascend forcefully - 'hebt gewaltsam sich,233 - and exclude and separate itself from the constellation of which it is a part.

These verses describe the body as an active willing soul whose forces are directed downwards. The divine soul, on the other hand, is directed ' $\mathrm{Zu}$ den Gefilden hoher Ahnen.' The activity of the body's will is resistance; it clings to life's promises and pleasures. The will of the other soul reflects a movement directed upwards

229 Ennead I. 6. 8. On the quotation from The Iliad see Armstrong's comments: op. cit. Vol. 1: p. 256.

230 W. R. Inge, The Philosophy of Plotinus, 3rd ed., 2 vols. (New York: Green Wood Press, 1968), Vol. 1: pp. 261-262.

231 Ennead I. 6. 8 (my emphasis).

232 V. 1112-1117.

233 V. 1116. 
and beyond this world. The resisting force here acts as an impediment to the process of reunification and purification. As the Ennead I. 8 mentions, matter in its incorporeal form (prime matter or hyle) stands against the One's first emanation, the Intellect. The resistance of prime matter against the One is called the prime evil in the Ennead I. 8. ${ }^{234}$ The resistance the divine nucleus faces on its path of ascent is the secondary evil. ${ }^{235}$ Near the end of the Osterspaziergang, Faust acts as 'der Weise' of the Ephemerides is expected to. Faust sees his being as an arena of constant struggle of the soul trying to separate itself from the corporeal and the force whose attention is devoted to the bodily. In the Platonic tradition that Plotinus follows, the body is the meeting place of the soul and matter. All the faculties of the soul are embedded in the body except for the direct presence of the One in the human soul. As the Ennead V. 1. 10-12 explains, this direct presence makes possible the recognition of beauty and goodness and stands in connection with the lower stages of the human soul. ${ }^{236}$ This connection between the divine nucleus and the other faculties of the soul weakens as the other stages turn their attention to the bodily realm instead of practicing purification and going through the process of abstraction:

First of all, this kind of soul is not outside matter or by itself. So it is mixed with unmeasuredness and without a share in the form which brings order and reduces to measure, since it is fused with a body which has matter. And then its reasoning part, if that is damaged, is hindered in its seeing by the passions and by being darkened by matter, and inclined to matter, and altogether by looking towards becoming, not being; and the principle of becoming is the nature of matter, which is so evil that it infects with its own evil that which is not in it but only directs its gaze to it. For since it is altogether without any share in good and is a privation of good and a pure lack of it, it makes everything which comes into contact with it in any way like itself. 237

Faust, like Plotinus, recognizes in the body a will (soul) that inclines toward matter, clings to distractions and prefers stagnation to ascension. This soul's corruption is due to its excessive attachment to the corporeal realm.

234 See Carroll's explanation of the prime evil in Ennead I. 8 in: William J. Carroll, 'Plotinus on the Origin of Matter', in Neoplatonism and Nature: Studies in Plotinus' Enneads, ed. Michael F. Wagner, Studies in Neoplatonism, Ancient and Modern (Albany: State Univ. of New York Press, 2002), p. 199.

235 Ennead I. 8. 4.

236 In the human soul as microcosm the divine nucleus represents the One. For all other stages of emanation, there is a corresponding stage in the intellectual faculty. Therefore, the Intellect and the reproductive and nourishing aspects have their likeness to the Soul of the World and the demiurgic aspect of the emanation. See the microcosm argument in Ennead V. 1. 10.

237 Ennead I. 8.4 (my emphasis). 
As I discussed above, we find multiple instances early in the drama in which Faust attempts to ascend beyond his earthly boundaries. On each such occasion, the sight of heavenly bodies - either the sun or the moon - provides the impetus for Faust to ascend. And in each case the body and its worldly attachments are seen as active impediments. In the form of houses, land, children and wives, these worldly attachments hinder the fulfillment of Faust's wish to reach the sun - 'ihr ew'ges Licht zu trinken'. 238

In each stage of the process analyzed thus far, we noticed that the transcendent truth, represented to Faust as the macrocosm sign, must have a homogenous immanence in the cosmos. Yet, compared to the Platonic view of the transcendence of truth, this view of homogenous immanence does not appear to have deep roots in Faust. This dominance of transcendence becomes clear when Faust faults his bodily and human condition for his failure to grasp the 'Erdgeist' - the personification of the immanence of the transcendent in nature. Faust's contempt for the body reappears in the scene Vor dem Tor. The view of transcendence of the intelligible content of the world from the bodily realm seems to be deeply seated in Faust's mind. Therefore, up to this point, we find no clear instance of a conception of the world in which those two spheres - to which his two souls, respectively, are attracted ${ }^{239}$ - were seen as parts of that one infinite harmony. In other words, Faust does not see himself as already part of the whole. Thus, he cannot grasp the place of the individual, the 'Ich', in his pursuit of knowledge.

The paradoxical state between Plotinus's call for purification and Goethe's view of immanence in his reinterpretation of the Ennead I. 6.9 sets the stage for the beginning of Faust's journey. In this paradoxical state, we begin to see the problematization of the Platonic view of the ascending pursuit of knowledge; the valorization of the body and soul relation; and the dramatization of 'Es irrt der Mensch so lang' er strebt. ${ }^{240}$

\section{I.3 Direct Approach to Knowledge of the Transcendent Truth in the Divan of Heāfiẓ.}

One important characteristic of the Divan is that Hāfiz edited each poem's form and content, again and again, over the course of his life. ${ }^{241}$ Therefore, although some historical characters are recognizable in his works, these characters

238 V. 1086.

239 V. 1112.

240 V. 317.

241 Zarrīnkūb, $A z$ kūče-ye rendān, p. 57. 
cannot be used to reliably construct the development of the poet's intellectual life. Scholars have not yet succeeded in categorizing the poet's works into distinct periods or stages. At best, historical facts within a given poem suggest when the gazal was first written; in a few cases, moreover, a poem's mood along with the king or patron named in the poem points to circumstances behind its initial composition. Yet Hāfiz is almost certain to have edited the poem at a later time. The problematization of different views and approaches takes the form of dialogues between opposing views. As we will see in the course of this study, Hāfiz often practices self-criticism - the poet's multiple standpoints have a polyphonic effect. This characteristic of the Divan invites comparison to Faust, which, as we saw in Faust's reading of the macrocosm sign and summoning the 'Erdgeist', also contains constant coexisting paradoxical views sometimes even in one character and in a single moment.

Haafiz considered himself a seeker of a form of knowledge relevant to the ethical dimension of life. The ascending negative approach to the acquisition of knowledge is an important part of the world-views that were handed down to him. As I explained earlier, Platonic views were one of the main sources of this approach. Intertwined with hikmat and Sufi theoretical discourse, Platonic views influenced interpretations of the Qur'ān and the hadit.

In the Divan, there are several poems that reflect the dominance of the abstract and ascending direct approach toward the transcendent truth. This approach includes self-denial and striving for the separation between body and soul - a condition for seeking and appreciating the truth. The small number of these poems and their discernible poetic style of linear form brings Arberry to conceive of an early phase in the poet's career. ${ }^{242}$ Falaki dedicates a section of his dissertation to exploring this putative early phase in the poet's life - a phase in which Hāfiẓ's gazals show traces of Sufi views. ${ }^{243}$ As far as poetic style is concerned, the comparison between linear and pāšān form does suggest that these poems were written when the poet was young. Yet if this argument leads to the conclusion that the young poet was a follower of a Sufi order, we should be skeptical - there is no evidence for Hāfiz’s belonging to any Sufi order. Even the great Sufi poet Ğāmī (1414-1449 CE) admits in his Nafaḥāt ul-uns that Haăfiẓ’s interest in Sufi terms did not reflect membership in a specific Sufi order. ${ }^{244}$ In fact, there

242 Arberry, Fifty Poems of Hiâfiz: Text and Translations Collected and Made, Introduced and Annotated by Arthur J. Arberry, pp. 29-30.

243 Maḥmūd Falakì, 'Goethe und Hafis - Verstehen und Missverstehen in der Wechselbeziehung deutscher und persischer Kultur’ (Hamburg, Univ., 2012), pp. 72-79.

244 Nūr ud-Dīn 'Abd ur-Raḥmān Ǧāmī, Nafaḥāt ul-uns (Tehran: Ketābforūšī-ye Sa'dī, 1336/ 1957), p. 614. 
is substantial textual evidence in the Divan suggesting that the poet disapproved of such membership. But as Ğāmī correctly explains, Sufi terminology and the theoretical and ethical aspects of hikmat that are shared with Sufi theory are present in poetic form in Hāfiẓ’s Divan.

\section{I.3.1 Escaping the Cage of the Body}

The body as an impediment to the soul's path to ascension and reunion - a topic discussed in Platonic and Neoplatonic sources ${ }^{245}$ - appears in the verses that follow:

[1] The dust of my body is becoming the veil in front of the face of the soul.

Oh happy the moment when from off that face I cast the veil aside!

[2] A cage like this is unworthy of a sweet singer like me.

I will go to the rose bed of Paradise, because I am the bird of that Garden.

[3] It is not clear why I came, where I was;

Pain and woe, that of my beginning and end I am unaware.

[4] How can I make my circuit in the space of the World of Holiness,

When, in the enclosed world of contrivance, ${ }^{246}$ I am tied to the plank of my body?

[5] If from the blood of my hear the scent of yearning comes,

Do not be surprised: I am the musk pod of the fellow sufferer of Khotan. ${ }^{247}$

[6] Have no regard for my candle-like gold-laced tunic of Taráz,

Because hidden under my shirt the burning are.

[7] Come and from him snatch away Háfiz's being:

With your being, nobody will hear from me, 'I am.'248

The gazal begins by defining the body in relation to the soul: the body is accused of being confusing, distracting and distorting, like dust that is kicked up from the earth as a person walks quickly or as a caravan leaves the gates of a city, depriving the lover of the sight of his or her beloved. The dust hides the face of the soul, and Haafiz impatiently waits for the joyous moment at which he may cast this veil aside. In the next couplet, the body is illustrated as a cage in which the nightingale of the soul feels imprisoned, longing for escape and ascent. The imprisoned soul then expresses its regrets for having forgotten its

245 Ennead I. 6. 8.

246 Clarke's translation - the mixed abode - is closer to the word Ḥāfiz employs in this verse. Sarāča-yi tarkīb means the abode of mixture that in contrast with fażāyi 'ālam-i quds (the space of the World of Purity) denotes the realm of mixture of body and the material. See: Clarke, 385, 4, p. 661; and Hูānlarī, 334, 4.

247 According to the literary tradition, Hutan is known as the habitat of the musk-deer.

248 Avery, CCCXXXIV, p. 413. 
home and its purpose in the narrow cage. There is an unexplainable wish to leave this worldly sphere behind and ascend to higher levels. Only the body impedes the wings of longing, for the soul now is in the abode of mixture. The term 'abode of mixture', sarāča-yi tarkīb, directly refers to the bodily realm, a mixture of four opposing elements, and the soul.

In the fifth couplet, Hāfiz turns to a form of argumentation strongly reminiscent of the anamnesis doctrine, which is articulated in elements and metaphors native to his cultural space. The argument employs the metaphor of the muskpod and its fragrance. This metaphor requires a brief elucidation. The musk-pods that one found in the bazaars during Haafiż's time were severed musk glands of the musk-deer. In the couplet above, the scent of this severed organ represents the memory of its far away home. Furthermore, its desirable and unique scent was believed to derive from droplets of blood that the heart-broken deer poured into this severed gland. The poet finds in his own bleeding heart the scent of musk as well; like the musk-pod, the poet's heart has been taken far away from its home, and this scent is a constant reminder that he is not from this sphere of mixture. ${ }^{249}$ As an incorporeal presence in the epistemic horizon of the poet, the scent activates the anamnestic process - an urge to elevate the segregated, individuated human and separate the body from the soul. ${ }^{250}$

The sixth couplet reveals a noteworthy aspect of Hāfiz's self-image as a human with all his longings: the body, the object under consideration, is not exhausted or famished by abstinence and self-denial. Rather, it is so graceful that the poet feels the need to explain that an 'inner burning passion' consumes his heart - even though he appears to be 'an ornamented candle' from the outside. Having started with metaphysical concepts of body and soul, the poem arrives at the metaphorical imagery of the candle. The candle burns throughout the night and gives to the beloved the light that she had kindled at the beginning of the night; as it burns, the candle waits for the moment at which it is extinguished by the beloved at sun-rise. In this moment, the candle can see its beloved one last time before it is annihilated. In the last couplet, the poet abandons his desire to forcibly remove the beloved's veil. He waits for her to come, expecting that her presence will resolve his individuality. In the end, the desire to see her face dominates the poem, but not as a personal wish for ascent; the poet depicts himself as a candle at midnight that awaits dawn. ${ }^{251}$

249 We must consider here the significance of scent and light in the Platonic context.

250 On anamnesis in the Divan see the following verses: Avery, XXXVII, 4-5, p. 68; Wohlleben, 335, 5-6, p. 437; Avery, CCCXXXV, 5-6, p. 414.

251 The metaphor of candle has many aspects, one of which I explained above. But we should note that this element of this literary tradition, like many others, goes through Ḥāfiẓ’s poetic 
The following gazal illustrates the relation between body and soul on an ascending path to truth:

[1] You without the news, strive to be its possessor.

So long as you are not a wayfarer, how can you be a guide?

[2] In the school of the Truths, before one versed in love,

Hey son, make an effort to become one day a father.

[3] Like the valiant of the Path, cleanse your hands of existence's copper,

To discover love's alchemy and turn it into gold.

[4] Sleeping and eating have distanced you from your proper rank.

You will come into your own when you get above sleeping and eating.

[5] Were the light of God's love to fall upon your heart and soul,

By God, you would be finer than the sun in heaven!

[6] Be drowned in the ocean of God a moment. Do not suppose

That by so much as a hair you will be wet from the waters of the Seven Seas:

[7] From head to foot all the light of God will be yours,

Once, headless and footless, you are on the path of the Lord of Glory.

[8] If the countenance of God should become the object of your sight,

From then on no doubt will remain that you are the master of insight.

[9] When the foundations of your being are turned topsy-turvy,

In the heart do not suppose that you will ever again be on top.

[10] If, O Háfiz, you have a mind for union,

At the door of the virtuous you must become dust. ${ }^{252}$

In the verses above, a goal is defined and a process is outlined for reaching it. Following the tradition of Plato's Symposium and Ibn Sīnā's Treatise on Love, ${ }^{253}$ love is the teacher who guides lovers on their journey. Yet love requires that lovers first recognize the lack of their goodness - i.e., they must admit that they are 'without the news' so that their appreciation for higher-level goodness puts in motion the process of ascent.

In the third couplet, Hâfiz invites the reader to undergo a process of transformation through which the reader relinquishes the 'copper' of his existence. The metaphor of 'existence's copper' refers to the individuated soul within the

productive process in which multiple allusions are combined in one instance. For further instances of the candle as a metaphor see: Avery, CCCXVII, 1, p. 394.; Clarke, 378, 1, p. 652.; Wohlleben, 317, 1, p. 415; and Avery CCCXX, 2, p. 397.; Clarke, 386, 2, p. 662.; Wohlleben, 320, 2, p. 418.; and Avery, CCLXXXIX, p. 360.; Clarke, 347, pp. 594-595.; Wohlleben, 289, p. 376.

252 Avery, CCCCLXXVIII, p. 579 (my emphasis).

253 Ḥusaīn ibn 'Abdullāh Sīnā, 'Resāle-ye 'Išq', in Rasā’el-e Ibn Sīnā. Translated by Ḍiyā’ udDīn Dorrī, ed. Dịyā' ud-Dīn Dorrī (Tehran: Markazī, 1360/1981), p. 123. Ibn Sīnā sees love as an existential and intellectual matter that stands in relation to the Goodness that is the Necessary Existent. All beings pursue it since they are attracted to the perfection in the Good in relation to their relative poverty of it. 
boundaries of the body. ${ }^{254}$ This process of ascent and purification is described as analogous to the process of turning worthless copper to gold through alchemy. The current state of ignorance and forgetfulness in which Hāfiz sees himself has its roots in what the Enneads describe as 'the secondary evil'. ${ }^{255}$ In the fourth couplet, sleep and eating keep us away from original purity; only by abandoning them our self will realize itself in the Self.

As the most precious objects in the visible world, the sun and its light are the destination for the process of ascent. If the light of God permeates his existence, the seeker may ascend beyond the goodness of the sun. The fifth and seventh couplets describe a light that is beyond what is aesthetically perceivable - the light of God as the Lord of Glory. Lord of Glory or Zūu-ğalāl refers to an aspect of the divine that is absolutely transcendent. Ğalāl describes the awe and fear that strikes the person who comes close to perceiving the divine. ${ }^{256}$ In contrast to the fear-inspiring divine majesty that is dominant in this gazal, the divine beauty (ğamāl) inspires bliss.

In the eighth couplet, the seeker relinquishes his ability to see the visible world but gains the ability to look directly toward the transcendent. By focusing exclusively on the radically transcendent divine, it is possible to become șâhib nazar - master of insight. We should note the importance of the term șähib nazar. The poet uses this combination of șăhib (lord, possessor) and nazar (view, vision, theory) when speaking within the horizon of exclusion and negative ascent to the truth. As the poem shows, this term belongs in the context of transcendence and majesty, rather than immanence and beauty. ${ }^{257}$ We can now go back to the Ennead I. 6.9 and observe how the eye becomes like the sun and how, after the soul's purification, truth is perceived in an excluding manner that transcends the particulars. There is a deep resemblance between these views and the intellectual content of the two gazals analyzed above.

These two gazals are characterized by their seriousness and absence of irony. In the Divan, however, Hāfiz frequently employs sarcasm to criticize religious puritanism and Sufi zealot asceticism - it is one of the Divan's defining features. The term 'master of insight' fits with the general ascetic Sufi tone of this poem. As the two gazals above prove, the poet was proficient in the theory

254 Muhammad Este lāmī, Dars-e Häfiz, 2 vols. (Tehran: Sohnan, 1382/2003), vol. 2: p. 1228.

255 Ennead I. 8. 4. See also the explanations of this point in the analysis of Faust p. 67 above.

256 Ṣādiq Goharīn, Šarh-e eștelāhăt-e taṣavvuf, ed. Ṣādiq Goharīn, 10 vols. (Tehran: Zawwār, 1368/1989), vol. 4: pp. 45-47

257 See Āšūrī's elaboration on the semiotic differences between șāhib nazar and nazar-bāz in the following: Dārīūš Āšūrī, 'Rindī va Naẓrbāzī', in Parsehā va porsešhā: Mağmū'e-ye maqālāt (Tehran: Našr-e Āgah, 1388/2009). 
of negative, direct ascent and the Sufi views that correspond to it. Considering the ubiquity of light metaphors and specifically the sun in the analysis that follows, I briefly discuss the significance of the sun for Islamic Neoplatonists. I then discuss the presence of the sun in the Divan as a metaphor for extramundane divine truth.

\section{I.3.2 The Presence of the Sun in Islamic Neoplatonism}

According to Ptolemy, there are nine spheres that revolve around the earth. This view influenced Fārābī's theory of emanation, according to which ten levels of Intellect emanate from the First Existent. ${ }^{258}$ In Fārābī's emanative system, the sun analogy explains the 'Active Intellect', ${ }^{259}$ a level of hierarchy of intellect comparable to that of Plotinus's Soul of the World. Active Intellect emanates the intelligibility of the cosmos and the power of apprehending it; the sun and the eye are the best analogies for the Active Intellect, Fārābi suggests.

The significance of the sun as the source of life for the Ihwān aṣ-Ṣafā suggests that they were influenced by the Stoic and Pythagorean views. Al-Nafs alkulliyah (the World Soul) is a simple essence emanated from the Intellect. The power emanated in the World Soul 'manifests' in the sun and then animates sublunary, material beings. ${ }^{260}$ Furthermore, the Ihwān aṣ-Ṣafā hold that the sun has a direct role to play in the formation of the human soul in the last stage before its natural birth. Farrukh explains the stages that a soul passes through, from its descent from the One to its human birth:

When a soul falls, it enters the ovum which happens to be impregnated at the time of its fall. This soul in the ovum comes soon under the regimen of the planets. All planets, beginning with the farthest one, Saturn, influence the incubation of the soul turn by turn for a whole lunar month. After the completion of the third month the fetus comes under the influence of the sun, the king of the planets, and life is breathed into it. ${ }^{261}$

In this manner, they conceive the bond between human beings and the sun to be existential.

258 Ibrahim Madkour, 'Al-Fārābi', in A History of Muslim Philosophy, ed. M. M. Sharif (Wiesbaden: Harrassowitz, 1963), p. 458.

259 Fārābī takes this name and the modified material of the levels of intellect from Aristotle's De Anima III. See: Majid Fakhry, Al-Fārābi, founder of Islamic neoplatonism, Great Islamic thinkers (Oxford: Oneworld, 2002), p. 73.

260 Farrukh, 'Ikhwān al-Ṣafā', p. 295.

261 Ibid., p. 298. 
In Metaphysica, Ibn Sīnā mentions the sun in the context of an analogy for the process of emanation. He concisely explains his reasons for using this analogy:

It has become evident, therefore, that there is a primary entity (awwali) in the world which is not in the world ('alam nist) though the being of the world comes from It. Its existence, which is necessary, is due to Itself. In reality It is absolute being (hast-i maḥd) and absolute existence (wujūd-i mahd d). All things exist due to It in the same manner as the light of the sun $(\bar{a} f t \bar{a} b)$ is due to itself, whereas the illumination all other things receive from the sun is accidental. ${ }^{262}$

In this section, I discussed the significance of the sun for the philosophers of the Islamic tradition. I also briefly explained the intellectual and ontological aspects of what the sun represents. I expand on these topics in the analysis of Ḥāfiz’s Divan that follows.

\section{I.3.3 The Mote and the Sun}

Just as we saw in the early scenes of Faust, the sight of the sun in Hāfiz’s Divan kindles a longing for ascent and unity with the source of illumination. But unlike the two gazals that we analyzed above, ${ }^{263}$ the verses that follow are polyphonic; they include multiple voices and paradoxes. These verses thereby resist any single interpretation. This quality is evident in the following gazal, in which the poet alludes to wine and juxtaposes the Arabs with the Persians:

[1] Happy that day when I go from this ruined stopping place.

I seek the soul's repose and I'm going in pursuit of the darling.

[2] Although aware that the stranger might not get anywhere,

I am proceeding by the perfume of that disheveled tress.

[3] With ailing feet and a powerless heart, like the breeze

I move in longing for that swaying cypress.

[4] Of the terror of Alexander's prison my heart sickened.

Let me pack my bags and go to the realm of Solomon.

[5] In his way, if going must be like a pen with the tip of my head,

With wound-enduring heart and weeping eye will I go.

262 Avicenna, The Metaphysica of Avicenna (ibn Sīnā): a Critical Translation-Commentary and Analysis of the Fundamental Arguments in Avicenna's Metaphysica in the Dānish Nāma-i 'alā'i (The Book of Scientific Knowledge), trans. Parviz Morewedge, Persian heritage series (London: Routledge \& Kegan Paul, 1973), p. 60.

263 The perfection of style and majority of these gazals in the Divan strengthens the scholarly speculations that suggest the two gazals in question belong to the early stages of the poet's career. 
[6] I vowed, should I one day emerge from this grief,

I would go to the wine temple in glee and singing a song;

[7] In desiring him, like a dancing mote

To the lip of the source of the dazzling sun I would go.

[8] The Arabs have no sorrow for the grief of the heavy laden;

O Persians, some help that I may go happily and with ease,

[9]And if like Háfiz I do not follow the route out of the desert,

I will go in the companionship of the party of the Ásaf of the Ages. ${ }^{264}$

An urge for escape permeates this $\dot{g} a z a l$. The poet wishes to leave the world that he perceives as a ruined abode in which the soul ( $\check{g} \bar{a} n)$ feels encaged. The expression of this overwhelming discontent finds explicit articulation in the radif of this gazal 'biravam' repeating the wish for escape. ${ }^{265}$ This soul seeks a path to the beloved ( $\check{g} \bar{a} n \bar{a} n$ ). In the second couplet, the seeker expresses that he feels like a stranger, yet he recognizes clues that he hopes will lead him to his homeland. In describing these clues, Ḥăfiz uses the Persian word $b \bar{u}$, which denotes both 'perfume' and 'hope'. ${ }^{266}$ The scent metaphors, like the light metaphors, represent the continual presence of the transcendent in the timeless act of emanation. The imagery of a disheveled tress from which this perfume permeates the world illustrates the seeker's attraction toward the object of pursuit. ${ }^{267}$ This attraction is intellectual insofar as it is based on the ability to appreciate higher goodness. In the fifth couplet, Hāfiz illustrates the difficulties that the seeker encounters on his path. It is important to note that, although this intelligible trace of the incorporeal realm is perceivable in the natural world, it cannot be fully enjoyed there. The interruption of immanence of the transcendent in the world makes the world resemble a prison for the soul - the Prison of Alexander (zindān-i Sikandar), as Hâafiz describes it. The poet wishes to flee to the kingdom of Salomon (mulk-i Sulaìmān) $)^{268}$ - a metaphor either for poet's literal place of origin (Shiraz) or his extramundane homeland.

264 Avery, CCCLI, p. 431.

265 Making use of a complete word as radif (rhyming word) shows the poet's readiness to sacrifice aesthetic perfection for direct communication of emotion.

266 Bahā' ud-Dīn Hुorramšāhī, Ḥāfiz-nāme, 2nd ed., 2 vols. (Tehran: 'Elmī va Farhangī, 1384/ 2005), vol. 2: p. 1013.

267 On scent metaphors in Neoplatonic tradition see p. 50 above.

268 Interpreters who take historical approaches read these two metaphors as a reference to the two cities of Yazd (Alexander's Prison) and Shiraz (Kingdom of Solomon) See: Husaīn 'Alī Heravī, Šarh-e ġazalhā-ye Ḥāfiz, 4 vols. (Tehran: Našr-e Nau, 1367/1988), pp. 1479-1489. And, Mu'īn, Ḥäfiz-e širinnsohan, pp. 119-124. However, the fact remains that these assumptions lack sufficient historical support, as Este lāmī shows in his comment on this ġazal: Este lāmī, Darse Hāafiz, vol. 2: p. 921. Furthermore, it should be noted that, even if this poem had been written only to encourage a patron to help the poet move from Yazd back to Shiraz, it is the rhetoric of 
In the eighth couplet, Hāfiz uses a play on words to change the tone of the poem. The two words tāzyān ('the riders' or 'the Arabs') and pārsāyān ('the virtuous' or 'the Persians') are juxtaposed to each other. Whereas the poet expects to receive no sympathy from the first group, he anticipates assistance from the second. The mention of a wine-house (translated above as 'wine temple') in the sixth couplet colors the word pārsāyān. This couplet brings remarkable variation to the gazal by suggesting that the path to the transcendent can be enjoyed. $^{269}$

After the sixth and eighth couplets change the tone of the poem, the form of the journey is modified as well. In the seventh couplet, Hāfiz employs the motif of the mote, an object that strives for the sun. The desire to reach the sun is expressed in the metaphorical imagery of the sun as a fountain toward which the mote strives and from which it wishes to drink. ${ }^{270}$ The intoxicating influence of wine transforms the upward movement into a joyous dance.

In another gazal in the Divan, the imagery of the mote and the sun appears again. In accordance with its intellectual context, love is described as motivating the act of elevation: 'You are not less than a mote. Do not be degraded. Practise love, | So that whirling now this side up, now that, to the private chamber of the sun you might arrive. ${ }^{271}$ In the couplet above, wine, love and the natural beauty are present, whereas pain is absent. Even the sun is connected to love through the choice of the verb. The compound verb that Hāfiz uses here is 'mihr varzidan.' In Persian, one of the words that signifies the sun is mihr. Yet mihr also means 'love', and 'mihr varzìdan' means 'making love'. In his choice of words, the poet articulates how natural it is that practicing love and ascending to the sun are one and the same.

As we have seen thus far, it is only in the first two gazals that the element of pleasure is absent in the poems. ${ }^{272}$ In the ascending process of abstraction,

ascent to the transcendent that is employed to make the poet's point - without this, the poem doesn't make any sense. It should be noted that allegorical poetic usage of these metaphors after Ḥāfiz can be seen in Șā'ib of Tabriz 17th CE. He explicitly uses the metaphor of Alexander's Prison for the realm of matter. See in: Șā’ib Tabrīzī, Kollìyāt-e Șā’ib Tabrīzì, 2nd ed. (Tehran: Haīyām, 1373/1994), pp. 508-509. Gazal: 1415, couplet: 2. The twofold meaning of these metaphors has been used in Persian literature, but the presence of other metaphors in this poem supports the possibility of a reading that goes beyond the mere expression of personal problems.

269 In the second and third chapters of this study we examine this aspect of the Divan.

270 In Faust v. 1086, we saw Goethe's illustration of the desire to reach the sun and the sensual experience of drinking its light. In the Divan, this transcultural ancient image appears to illustrate the same intense longing.

271 Avery, CCCLXXX, 4, p. 463. 
on the other hand, stress was placed on the painful experience of being in a world in which the transcendent truth is absent.

\section{I.3.4 Masīhā (Christ) and the Sun}

To discuss the significance of Masīhā - Christ - in the Divan of Hāfiz, we need to consider Christ's significance in the poet's cultural horizon. Earlier, I mentioned that Hāfiz associates Christ with the sun. ${ }^{273}$ As Wohlleben points out, the poet sees Christ as 'besonders reiner Mensch'274 on account of his immaculate conception with the emanation (fayażān) ${ }^{275}$ of the Holy Spirit (Rūh ul-Qudus), which is the 'grace and power' ${ }^{276}$ of the Holy Ghost that makes Christ Rūhullāh or the 'Soul of God' in Islamic theology. ${ }^{277}$ In this context, Christ is the second human being after Adam who was born directly from God's soul. The Quranic verses relevant to this subject can be found in the Surah al-Nisa ' ' (Women). ${ }^{278}$

It is noteworthy that, in the Qur'ān, the titles Word of God and Soul of God are reserved only for Christ. ${ }^{279}$ This exclusive characteristic of Christ in the Qur'ān reflects itself in the views of Ahmad ibn Hayāt, an Islamic rationalist theologian of the Mu'tazili school of the ninth century CE, who 'held that there are two deities: one, the creator and eternal deity, and the other, the created one which is Jesus Christ, the son of Mary. He regarded Messiah as the Son of God. On account of this belief he was considered to have renounced Islam' ${ }^{280}$ These extraordinary characteristics of Christ reflect themselves in the conviction that, Jesus ascended to the house of the sun. ${ }^{281}$

273 See the citation and explanations on p. 30.

274 See footnote to Wohlleben p. 52.

275 See in: Clarke, 123, 9, p. 259. Here, Clarke translates fiyż as 'bounty'. Hāfiz sees the power in Christ in the contribution of emanative grace of the Holy Ghost: Fiyżi Rūh ul-Qudus

276 See G. Payne's translation in: Arberry, Fifty Poems of Häfiz: Text and Translations Collected and Made, Introduced and Annotated by Arthur J. Arberry, p. 99.

277 Horramšāhī, Hâafiz-nāme, vol. 1: pp. 326-327.

278 The Glorious Kur'an, trans. Abdallah Yousuf Ali, 3rd. ed. (Beirut: Dār al-Fikr, 1938), 04, 171, p. 233-234.

279 Other prophets have titles in the Qur'än which depict them in a relation to God and not as an extension and will of God as soul and word. For instance, Abraham has the title of God's friend: Halī ullāh. And Moses's title is 'the one who converses with God': Kalīm ullāh

280 Mir Valiuddin, 'Mu'tazilism', in A history of Muslim philosophy: With short accounts of other disciplines and the modern renaissance in Muslim lands, ed. M. M. Sharif (Wiesbaden: Otto Harrassowitz, 1963), p. 211.

281 See in Qur'ān (04: 158) 'Nay, God raised him up | Unto Himself; and God | Is Exalted in Power, Wise'. The Glorious Kur'an, p. 230. 
In the poet's view, whenever we think of miracles and the final ascent of Christ, we must consider that the humanity of Christ is dissolved in the grace of God. This privileged state is reserved for him and whomever else God may choose. ${ }^{282}$ Hāfiz recognizes the magnificence of those who, like Christ, ${ }^{283}$ have dissolved the boundaries of their individuality. He believes that they may experience a divine existence - but if so, 'by grace of the Holy Spirit' rather than by their own efforts. Yet it is vitally important to note that Hāfiz does not in any way personally identify with the Masīhā; he considers himself a simple human being.

In two different gazals in the Divan, Hāfiz treats the difference between Masịhā and others regarding their respective desires for transcending to the sphere of the sun. Since the term that Haafiz uses in the following gazal is difficult to capture in translation, I make use of German and English translations alongside the transliteration of the original Persian:

\author{
Masīhā-yi muğarrad rā barāzad \\ Ki bā huršìd sāzad ham-vis $\underline{a} q \bar{i}^{284}$ \\ Mit Sonnen ein Bündnis zu schließen, geziemet \\ Dem Herrn Jesus nur allein ${ }^{285}$ \\ The lonely (un-married) Masīhā, it suiteth \\ That, fellowship with the sun, he should make ${ }^{286}$
}

Muğarrad is the word that Hāfiz uses to describe Christ (Masīḥā). This word is originally Arabic, but it is commonly used in Persian to mean 'single' or 'unmarried.' It also signifies being lonely, and literally it means 'naked' and 'pure'. ${ }^{287}$ But in the context of Sufism and especially hikmat, the term is best translated as 'abstract' - i.e., being purified in the process of negation of all that is attributive, corruptible and 'âriżi or being stripped to the essence (zzât). In Kašf ul-mahğūb, a canonical Sufi text written by Huğvīīi in the tenth century, we learn two major points: first, the writers of the Sufi tradition use the term muğarrad exclusively for Christ; and, second, in this context, muğarrad does

282 See Huānlarī, 136, 7; Avery, CXXXVI, 7; Clarke, 123, 9, p. 259.

283 In the context of the Divan, based on instances in which Christ is mentioned together with Ḥallāğ, it is most probable that Ḥāfiz means Manșūr-i Ḥallāğ, born 857 C. E. in Ṭūr, a village in Shiraz, and crucified on the charges of blasphemy, heresy, sorcery in Bagdad on March 26, 922.

284 Qazvīnī \& Ġanī, 460, 13, p. 323.

285 Hammer-Purgstall, XL, p. 417.

286 Clarke, 534, 13, p. 876 (my emphasis).

287 See Pourjavady's explanation of the term Tağrīd in: Ahmad Ġazzālī, Sawāniḥ, ed. Nasrollah Pourjavady (Based on Hellmut Ritter's edition) (Tehran: Entešārāt-e Bonyād-e Farhang-e Iran, 1359/1981), p. 89. 
not mean unmarried or lonely. Huğvīrī quotes Ǧunayd, a prominent Sufi of the ninth century:

Sufism is founded on eight qualities exemplified in eight Apostles: the generosity of Abraham, who sacrificed his son; the acquiescence of Ismael, who submitted to the command of God and gave up his dear life; the patience of Job, who patiently endured the affliction of worms and the jealousy of the Merciful; the symbolism of Zacharias, to whom God said, 'Thou shalt not speak unto men for three days save by signs' (Kor. iii. 36), and again to the same effect, 'When he called upon his Lord with a secret invocation' (Kor. xix, 2); the strangerhood of John, who was a stranger in his own country and an alien to his own kin amongst whom he lived; the pilgrimhood of Jesus, who was so detached therein from worldly things that he kept only a cup and a comb - the cup he threw away when he saw a man drinking water in the palms of his hands, and the comb likewise when he saw another man using his fingers ${ }^{288}$

In the original Persian, Huğvīrī writes: 'va ba sīyāḥat ba 'Īsā ki andar sīyāḥat-i hud čunān muğarrad būd ki [...]'. ${ }^{289}$ We see clearly that the attribute muğarrad is applied to Christ three hundred years before Hāfiz and refers to his ability to negatively purify himself - or as Nicholson translated it, to detach himself from whatever is unnecessary and other than God.

It is evident that these terminological details were not considered in the above translations of Hāfiz’'s couplet. Therefore, tağrīd ('abstraction') is not recognized as a term and the translations lack an important semantic aspect. In light of the terminological context, we may infer that in the Divan the quest for the fellowship of the sun - the quest to become its housemate or roommate, as the word ham-visāqi suggests - is only suitable for Christ. Moreover, the process of profound abstraction and purification from the material realm is reserved for those whom God chooses. Purification cannot be achieved through extreme asceticism or rejection of the mundane and bodily concerns, as early Sufis such as Huğvīī believed.

Now that we have the necessary understanding of the term tağrīd and its relation to Christ in the Divan, we may turn to the gazal from which it was cited. The poem describes the state of separation: 'From not seeing the beloved, blood became my heart; | Now evil befall the days of separation!'290 Earlier, we saw that this state was compared to a prison cell. Now, in addition to the state of separation, the text provides us with further contextual

288 Alí B. 'Uthmàn Al-Jullàbí Al-Hujwírí, The Kashf al-Mahjúb: The Oldest Persian Treatise on Sufism, ed. Reynold A. Nicholson, trans. Reynold A. Nicholson, 2nd ed., E. J. W. Gibb Memorial (London: Lowe and Brydone, 1959), Chapter III. On Sufism pp. 39-40 (my emphasis).

289 'Alī ibn 'Uțmān Huğvīrī, Kašf ul-maḥ̆ḡủb (Tehran: Amīr Kabīr, 1336/1957), p. 45.

290 Clarke, 534, 3, p. 875. 
information through which to understand the poem - namely, the poet's age and his view of the world: 'Back to my recollection, youthfulness bring-- I The sound of the harp and the hand-waving of the Sākì. ${ }^{291}$ The speaker is old but not blind to the pleasures of life. He even advises himself to be moderate in drinking wine: ' $O$ daughter of the vine! the pleasant bride, thou art; | But, sometimes, worthy of divorce, thou art. ${ }^{292}$ Here again, Haafiz expresses the view that pleasure is possible even in the state of separation from the beloved: 'O minstrel, sweet singer, sweet speaker! prepare | An 'Irāk note in Persian verse. ${ }^{293}$ At this point, we may turn to the next $\dot{g} a z a l$ in the Divan in which the sun and Christ are present.

In this next gazal, the poet's gaze is fixed on the night sky as he introspectively reflects on the different meanings that the sky and the heavenly bodies have for him. The first couplet describes the state of feeling the proximity of death as the poet looks at the slender crescent of the new moon resembling a sickle's blade; the shape of this heavenly body reminds the poet of judgment day (the season of harvest): 'I saw the green meadow of the Firmament and the sickle of the new moon. I I remembered my own sowing and the time of reaping. ${ }^{294}$ In this dark night, Hāfiz sets the stage for the presence of the sun; he describes his time on earth as the night and his approaching death as the dawn: "I said, "O luck, you were sleep and the sun has come up." | It answered, "In spite of all this, do not despair of the foreordained.",295 The poem's narrator - one of several voices in the poem - contrasts the everlasting life of the heavenly bodies to the short lives of human beings. After death, he reflects, one has to stand before the judgment of the absolute. At this point, another voice speaks of an event in the past that may be the origin of hope. After this voice revives the poet's hope, the voice mentions Christ and the sun as reasons for entertaining such hope.

\footnotetext{
291 Clarke, 534, 6.
}

292 Clarke, 534, 12.

293 Clarke, 534, 5. For explanation of the musical term ('Irāk note) or șaut-i 'Irāqì see p. 29 above. It should be noted that this gazal is an instance in the Divan in which Haafiz displays his mastery in emulation of the works of other great poets. He writes in the same rhyme and the same meter as his predecessor 'Irāqī did in two gaazals where 'Irāqī also uses the very words Masīhā-yi muğarrad, and ham-vis̄âqui. It is worth mentioning that 'Irāqī's usage of this word is in the context of Sufi-love. No poet before him used this word as frequently as 'Irāqī. See the following two ġazals: Faḩr ud-Dīn 'Irāqī, Mağmū'e-ye āșār-e Fah̆r ud-Dīn 'Irāqī, ed. Nasrīn Muhtašam (Tehran: Zawwār, 1372/1994), pp. 71-72; 146-147.

294 Avery, CCCXCIX, 1, p. 484.

295 Avery, CCCXCIX, 2, p. 484. 
Ānčinān rau šab-i raḥlat ču Masīhā ba falak

Kaz čirāq-i tu ba huršĩd rasad șad partau. ${ }^{296}$

On the night of departure, go to the heavens like Messiah,

So that from your lamp a hundred rays might reach the sun. ${ }^{297}$

In der Nacht der (großen) Reise mach dich, so rein wie der Messias, auf in den Himmel,

So daß von deinem Licht zur Sonne hundert Strahlen gelangen. ${ }^{298}$

Although the poet is anxious about losing time, since he hasn't yet attained detachment in this life, the guiding voice connects Christ's ascent to the sun to an event in the past that may be understood as an allusion to God's breathing life into Adam (Qur'ān, 15:29). Death is referred to as a state in which the soul (breath of the divine) goes back to its original state of purity. Therefore, there is hope that the soul after death will be as pure as Christ's soul during his life. Remarkably, the poet is not in a position to educate others; he listens to the voice along with his readers. In the seventh couplet, this voice goes a step further by criticizing the notion that the heavens are more elevated than humans and that humans should reach for them. This juxtaposition of heaven and human alludes to the story of original sin in which (according to the Islamic tradition) Adam and Eve eat the forbidden grain - wheat. Interestingly, the poet satirizes the event by replacing wheat with barely corn, a much cheaper grain - and, therefore, one eaten by poor - during the time of the poem's composition: 'Tell the heavens not to deck themselves out in all this pomp, because in love I The moon's harvest would fetch one barely corn, and the cluster of Pleiades, two. ${ }^{, 299}$ The guiding voice belittles the heavenly bodies in front of humans. It mentions that humans are not only not repentant of their original sin, but that they are ready to give up paradise for an even lesser price - it is the only way for them to become capable of love.

We face the following questions: why is the poet himself still inclined to a path of purity, despite that the guiding voice tries to open his eyes to another perspective? Does the voice in fact advise the poet to turn his back to religion by abandoning the ascending approach that entails ascetic negative methods? The following couplet of this gazal belittles the heavenly bodies and suggests: 'From your mole may the Evil Eye be far, because on the chequer-board of beauty

296 See Hูānlarī, 399, 3. See also Qazvīnī \& Ġanī, 407, 3. In Qazvīnī \& Ġanī’s edition the Masīh is described with the adjective muğarrad.

297 Avery, CCCXCIX, 3, p. 484.

298 Wohlleben, 399, 3, p. 508.

299 Avery, CCCXCIX, 7.

300 Ibid., 6. 
I It has moved a pawn by which the moon and the sun lost the wager. ${ }^{300}$ A new set of metaphors emerge. The sun and the moon that belong to the ascending context are juxtaposed to the mole on the face of the beloved. ${ }^{301}$ In the discourse of ascent, we know that the sun stands for the Beauty and Truth and that the moon represents a lower level of emanation. In this couplet, the mole of the beloved is compared to the player who starts a game of chess by moving a pawn - the most insignificant piece on the board. With this move, the beloved beats the sun and the moon. From the verses we have analyzed thus far, therefore, we can infer that the mole of the beloved is a modification of the metaphor of the sun, redefined to reflect a new understanding of the relation between the transcendent and the world. We are now in a position to answer the first question above: the poet confronts his own finitude whenever he looks toward the sun, yet he is also aware of other ways of grasping the relation between the transcendent and the world. The beauty of the gazal is that the poet is not depicted as someone who has purified himself in the path of abstraction; in other words, the poet is represented neither as a teacher of new ways nor as an ardent follower of the older method. Rather, the reader relates to him and experiences the flow of the verses in real time.

The last couplet provides an answer to our second question. The voice of the guide invites us to be proud of original sin - and thus of our inclination to beauty and love. ${ }^{302}$ Does Hāfiz thereby mean to critique religion in the form of hikmat and Sufism? 'The fire of hypocritical asceticism will burn up the grain heap of the Faith; | Throw off the woollen cassock, Háfiz, and go. ${ }^{303}$ As we see in this couplet, the voice warns against a false notion of the method of pursuit of truth that the narrator appears to endorse. This couplet concludes the gazal by characterizing asceticism - and its symbol, the woolen garment (hirqa-yi pašmina) - as the wrong notion, one that jeopardizes the common understanding of religion (din).

300 Ibid., 6.

301 In the last chapter we will turn to the imagery of the face of the Beloved which includes the mole.

302 Consider that in the Enneads and Islamic Neoplatonic views the inclination of the soul to the body is considered the reason for the fall; therefore, the ascending path to return includes abstraction and disregarding the body. See the Ennead IV. 8. 7. Farrukh points out that, according to Ihwān aṣ-Ṣafā, the entanglement of the soul with the material realm and its neglect of the heavenly glory was the reason for the fall: Farrukh, 'Ikhwān al-Ṣafā', p. 297.

303 Avery, CCCXCIX, 8, p. 484. 
Gūšvār-i zar-u la'l arči girāndārad gūš

Daur-i hūbi guzarān ast nașyhat bišinau

The ear may be heavy with earrings of ruby and gold,

But beauty's season is transient. note the warning. ${ }^{304}$

Ḥăfiz's self-criticism is articulated by the guiding voice who points out that he neglects the beauty of this world for the material rewards of extreme negation. The voice sarcastically refers to the weight of the expensive earrings while the poet metonymically alludes to becoming hard of hearing (girāndārad gūš) after being rewarded for submission to suppressive ascetic rulers. ${ }^{305}$ The contrast between the desirable rewards and the ability to hear admonition is the key to appreciating this couplet's social critique.

Thus, Haafiz does not turn his back to the transcendent itself, but rather criticizes the negative and excluding approach toward it. Furthermore, he sees a great danger in the pursuit of this path taken to an extreme. Such a pursuit is only for the few chosen ones, such as Christ. For normal human beings such as the poet himself, the process of abstraction must be seen in relation to the breath of God, which separates from the body after death. The fifth couplet conveys the reason for Adam and Eve's proud choice of beauty over abstraction. This choice is what Hăfiz sees as the true religion, which negative approaches can burn and corrupt.

One of the beauties of the Divan that differentiates it from works like those of Šāh Ni'matullāh, a Sufi-poet contemporary to Ḥāfiẓ, is that the Divan contains a critique of social and ethical problems. Such critique often takes the form of the poet's self-criticism or criticism directed to him by others. The reader of the Divan may try to imitate the abstract Christ, turning away from the pleasures of the beauty of the world. By doing so, the reader sympathizes with the poet and progresses through the poet's own stages of self-criticism. He thereby arrives at a new perspective and sees the possibility of achieving detachment after death, as the soul returns to its abstract form. In fact, the Divan does not abandon the possibility of giving up life in favor of experiencing such an abstract state. In the following section, I address this issue in the Divan.

304 Avery, CCCXCIX, 5, p. 484.

305 Compare to 'Abd ul-Ḥusaīn Zarrīnkūb, 'Ešārātī dar ḥāšīe-ye Dīvān-e Ḥāfiz’, in Naqš bar āb (Tehran: Mu'īn, 1368/1989), p. 405.; Heravī, Šarh-e ġazalhā-ye Ḥāfiz, vol. 3: p. 1692. 


\section{I.3.5 Self-Annihilation as the Last Hope for Ascent and Union}

According to the Platonic tradition, the path of purification runs against the ultimate barrier - the soul is trapped inside the body and is constantly deceived and misled by it. In the Phaedo, we saw that philosophy was defined as practice of death and as abstracting the soul from the origin of error. We also pointed out that Socrates abandoned hope of experiencing the transcendent truth within the body ${ }^{306}$; suicide presented itself as a way to achieve the abstraction that the seeker of knowledge strives for.

Yet the seeker of truth who resorts to suicide alters his ability to perceive the truth, because he reverses the typical passivity of death. The main argument of Socrates against suicide stresses this act of will:

I suppose that you wonder why, when other things which are evil may be good at certain times and to certain persons, death is to be the only exception, and why when a man is better dead, he is not permitted to be his own benefactor, but must wait for the kindness of another. ${ }^{307}$

Destroying something that belongs to the gods and not the mortals is unlawful, Socrates thought. Even in this philosophical text, this law remains a mystery; philosophy can do nothing other than provide an analogy:

I admit the appearance of inconsistency in what I am saying; but there may not be any real inconsistency after all. There is a doctrine whispered in secret that man is a prisoner who has no right to open the door and run away; this is a great mystery, not to be easily apprehended. Yet I too believe that the gods are our guardians, and that we men are a chattel [sic] of theirs.

Do you not agree?

Yes, I quite agree, said Cebes.

And if one of your chattels [sic], an ox or an ass, for example, took the liberty of putting itself out of the way when you had given no intimation of your wish that it should die, would you not be angry with it, and would you not punish it if you could?

Certainly, replied Cebes. ${ }^{308}$

The same urge tempts the poet in the Divan in many cases - namely, to shorten the path to transcendent truth through an act of free will. This problem appears in the Divan in a number of gazals and takes the form of a dialogue between the poet and the beloved or simply as the poet's self-criticism.

306 See Plato, 'Phaedo', p. 417. 66 e.

307 Ibid., pp. 411-412, 62, a (my emphasis).

308 Ibid., p. 412. b \& c. 
The seeker of union with the transcendent is ready to sacrifice his life in order to fully experience its Goodness: 'By his soul, if my life were at my disposal, | It would be the least of his slave's offerings. ${ }^{309}$ However, what holds him back is that he (like Socrates) does not consider himself the owner of his own life.

The other issue concerns the act of free will regarding something that the poet does not see as his own. Hāfiz sees the matter in the context of the relation between an act of free will and elevation to a higher state. In the verses that follow, this problem finds poetic articulation in the image of kissing the beloved:

When my life became the sacrifice for Thy lips I established the fancy

That a drop of its limpid water to the palate of ours falleth.

The fancy! Thy tress spake saying: 'O Lover! make not (thy) life the means (of desire);

'For, of this kind, many a pray into the snare of ours falleth.'310

In his fantasy, the poet is about to give up his life to join the beloved in union. But the beloved, looking at his proud face, responds that his life is not a rare gift at all - the beloved has countless lives at her disposal. Furthermore, the poet is wrong to suppose that an offering will suffice to attain union. As I mentioned earlier, even in the case of the poet's highest example, i.e., Christ, the ascent is not the result of any direct action on the part of the seeker himself. Offering life to the source of life is futile - not for lack of free will, but rather because there can never be anything greater than the transcendent. Nothing can force the transcendent to react in a certain way. ${ }^{311}$

In the Sufi context, the term for ultimate abstraction and emptiness is fan $\bar{a}^{\prime}$ - annihilation. In the twentieth chapter of Šahāb ud-Dīn Abū Ḥaș Suhravardī's (539-632/1145-1234) 'Awārif al-ma'ārif, we find a categorization of such abstraction in two levels: first, there is the outward abstraction in which the seeker of the truth experiences unity with haqq ta' $\bar{a} l \bar{a} .{ }^{312}$ In other words, the seeker should be unable to distinguish haqq ta'âlä's will from his own. In the second stage of abstraction - the inward fan $\bar{a}^{\prime}$-, all existence is dissolved in the One. ${ }^{313}$ The self-knowledge attained in the first stage allows the will of

309 Avery, CCCCXXXIII, 1, p. 523.

310 Clarke, 217, 5-6, p. 399. See: Avery, CCCCXXXIII, 5-6, p. 523.

311 Consider that in Neoplatonic philosophy the transcendent can logically never be influenced. As we discussed earlier, the reason for the One being named the Necessary Existent by Ibn Sīnā (a Neoplatonist) was that it cannot be consequent to anything.

312 Abū Ḥafṣ Suhravardī uses the word Transcendent Truth (Haqq Ta'ālā).

313 'Umar ibn Muḥammad Suhrawardī, 'Awārif al-ma'ārif, 2 vols. (Cairo: Maktab atTaqāfa ad-Dīnīya), p. 171. Compare to: Shaikh Shahab-ud-Din 'Umar B. Muhammad 
the individual to fade into that of the One. Thereby, the seeker of truth's personal wish for ascent must also fade into the will of the One.

This theme finds another expression in the Divan in the form of selfcriticism, as Hāfiz speaks to himself: 'Life is base coin, Háfiz: | For festive confetti it's not good. ${ }^{314}$

With such knowledge, the seeker of the truth has only one choice - to wait for the will and mercy of the beloved. Or as Socrates said in the quote above, to 'wait for the kindness of another' to free the seeker from the world in which absolute knowledge of the truth can never be attained. Hāfiz illustrates the experience of waiting for union and death in the following couplet: 'This borrowed life the Friend entrusted to Háfiz, | One day I might see His face, and this life surrender. ${ }^{315}$ The surrendering of force, as we demonstrated, is the result of the self-knowledge that Hāfiz has regarding the nature of the transcendent truth. In his symbolic metaphorical mode of articulation, he conveys this aspect of his world-view to his readers.

\section{I.4 Body and Soul in Direct Pursuit of Knowledge of the Transcendent in Goethe's Faust and the Divan of Ḥāfiz}

\section{I.4.1 Direct Negative Pursuit of Transcendent Truth}

Before proceeding to the next chapter, I summarize the findings of this study thus far. I have argued that both texts illustrate a negative method of attaining knowledge based on exclusion of the corporeal realm. This method accords with Neoplatonic epistemology and ethics which consider the body a mixture of soul and matter, each striving in opposite directions. The soul seeks to ascend and exclude the material realm so that it can reunite with the ultimate truth.

\section{I.4.2 Light Metaphors and the Call for Ascent}

In both texts we encounter a plethora of metaphors of heavenly bodies and light that draw on the Platonic tradition. The relation between these metaphors and the influence they have on their observers bring to light one way of

Suhrawardy, The 'Awarif-u '-Ma' arif, trans. H. Wilberforce Clarke (Lahore: Sh. Muhammad Ashraf, 1979), p. 196.

314 Avery, CLIX, 7, p. 215.

315 Avery, CCCXLIII, 7, p. 422. 
evaluating the relation between body and soul on the path to acquire knowledge. In section I.2 (discussing Faust) and sections I.3.3 and I.3.4 (discussing Hāfiz's Divan), I showed that the sight of the sun and the moon gives rise to a desire for ascent. In the following chapter, I trace how these metaphors evolve against the background of the body and soul relationship in the two texts.

\section{I.4.3 Suicide as a Failed Method of Ascent}

In the scene Nacht of Faust, the heavenly bodies kindle Faust's desire to ascend to the truth and address the full moon. They also shape metaphorical expressions of Faust's wish to fly toward the setting sun and drink from its eternal light. ${ }^{316}$ We also observed that each attempt to reach directly for the heavenly body results in pain and failure; and Faust's escape into fantasy only results in further failure.

In Faust, this circular pattern signifies a crisis, which Faust attempts to resolve through suicide. His suicide attempt is an expression of his despair at the possibility of realizing his desire of direct ascent while alive. In other words, his suicide attempt results in the realization that the individual can never attain to his goal qua individual; he needs to be annihilated in the extramundane nonindividuated truth.

In the Divan, we find a similar desire for direct ascension to the sun as a metaphor for the transcendent truth. The negative method of abstraction of the soul from the body results in similar reoccurring experiences of pain and alienation from the world. ${ }^{317}$ The limitations of the body make it impossible for the seeker of knowledge to attain to his desired level of ascent. This problem brings the question of suicide, once again, to the foreground. Yet Haafiz refutes suicide with arguments resembling those of Socrates in Phaedo. ${ }^{318}$ Furthermore, Hāfiz's poems show that the absolute abstraction from the body is reserved for the Masīhā; although it is conceivable that the Holy Ghost bestow this grace on others, the abstraction in question cannot be achieved through a negative process in life. ${ }^{319}$

316 For textual articulations of the desire to drink the light of the sun in the Divan of Hāfiz, see p. 77 above. Regarding this metaphorical expression in Goethe's Faust, see p. 64 above.

317 See the gazals cited and analyzed on $\mathrm{p} 70$; 72 above.

318 See §I.3.5 ('Self-Annihilation as the Last Hope for Ascent and Union').

319 See §I.3.4 ('Masīhāa (Christ) and the Sun'). 


\section{I.4.4 A Critical Look into the Method of Seeking Knowledge}

Both texts present poetic articulations of a rising consciousness about problems that arise from methods of radical purification and exclusion. In the scene Nacht, a conflict is dramatized between (a) a world-view based on the active immanence of the transcendent in the world; and (b) Faust's multiple failed attempts at ascent for which he holds the body responsible. This conflict shows that Faust's actions and views at this stage in the drama are deeply grounded in a radically transcendent view of the world - a view that keeps him segregated from nature and isolated from people. By the end of the scene Osterspaziergang, however, Faust becomes aware of the failure of the method of negative acquisition of knowledge. In the next chapter, I elaborate on Faust's process of leaving this method behind.

In the Divan of Hāfiz, sensory experiences of natural beauty oppose the method that seeks to exclude everything other than the One. A voice speaks to Hāfiz, warning him about the problems of radical ascetic exclusion. ${ }^{320}$ Then the poet himself expresses his critique of this ascetic outlook. He realizes that these extreme ascetic views have filled his world with pain and prevented him from appreciating beauty. Hāfiz seeks the help of the Persians - from whom he expects sympathy with his human situation - to find an aesthetically pleasing path through the world. ${ }^{321}$

In both texts, we find an expression of a need for external assistance: Faust seeks the help of the souls reigning between heaven and earth, and Haafiz seeks the help of the Persians. In the chapter that follows, I explore in both texts the process of shifting away from a transcendent world-view. I also investigate the specific mediations introduced in this process and the state of the body and soul.

320 See the analysis of the presence of this voice on pp. 81ff above. 321 See p. 77 above. Compare to Clarke, 391, 5, pp. 669-670. 